\title{
Cryptosporidium infections in terrestrial ungulates with focus on livestock: a systematic review and meta-analysis
}

\author{
Kareem Hatam-Nahavandi', Ehsan Ahmadpour ${ }^{2^{*}} \mathbb{D}^{1}$, David Carmena ${ }^{3}$, Adel Spotin ${ }^{4,5}$, Berit Bangoura ${ }^{6}$ \\ and Lihua Xiao ${ }^{7 *}$
}

\begin{abstract}
Background: Cryptosporidium spp. are causative agents of gastrointestinal diseases in a wide variety of vertebrate hosts. Mortality resulting from the disease is low in livestock, although severe cryptosporidiosis has been associated with fatality in young animals.

Methods: The goal of this systematic review and meta-analysis was to review the prevalence and molecular data on Cryptosporidium infections in selected terrestrial domestic and wild ungulates of the families Bovidae (bison, buffalo, cattle, goat, impala, mouflon sheep, sheep, yak), Cervidae (red deer, roe deer, white-tailed deer), Camelidae (alpaca, camel), Suidae (boar, pig), Giraffidae (giraffes) and Equidae (horses). Data collection was carried out using PubMed, Scopus, Science Direct and Cochran databases, with 429 papers being included in this systematic analysis.

Results: The results show that overall $18.9 \%$ of ungulates from the investigated species were infected with Cryptosporidium spp. Considering livestock species (cattle, sheep, goats, pigs, horses and buffaloes), analysis revealed higher Cryptosporidium infection prevalence in ungulates of the Cetartiodactyla than in those of the Perissodactyla, with cattle (29\%) being the most commonly infected farm animal.

Conclusions: Overall, the investigated domestic ungulates are considered potential sources of Cryptosporidium contamination in the environment. Control measures should be developed to reduce the occurrence of Cryptosporidium infection in these animals. Furthermore, literature on wild populations of the named ungulate species revealed a widespread presence and potential reservoir function of wild life.
\end{abstract}

Keywords: Cryptosporidiosis, Livestock, Cattle, Sheep, Goat, Pig, Horse, Wildlife

\section{Background}

Cryptosporidium, the causative agent of cryptosporidiosis, is an ubiquitous protozoan parasite. It causes gastrointestinal disease in a wide variety of vertebrate hosts, including ungulates of the orders Artiodactyla and Perissodactyla, as well as humans. Several Cryptosporidium species are known to be zoonotic with animals as major reservoirs [1]. In resource-limited settings,

\footnotetext{
*Correspondence: ehsanahmadpour@gmail.com; Ixiao1961@gmail.com

${ }^{2}$ Infectious and Tropical Diseases Research Center, Tabriz University

of Medical Sciences, Tabriz, Iran

${ }^{7}$ College of Veterinary Medicine, South China Agricultural University,

Guangzhou, China

Full list of author information is available at the end of the article
}

cryptosporidiosis is a leading cause of diarrhoeal death in children younger than five years across the globe, only second to rotaviral enteritis [2]. Cryptosporidiosis is also a significant contributor to health care cost in developed countries. It is estimated that in the USA 748,000 cases of human cryptosporidiosis occur annually [3]. Residents of and travelers to developing countries may be at greater risk of infection due to poor water treatment and food sanitation $[4,5]$. Cryptosporidiosis typically induces self-limiting diarrhea in immunocompetent individuals, but the infection can be severe and life-threatening in immunocompromised subjects [6]. It is one of the most important diseases in young ruminants, especially neonatal calves $[7,8]$. The clinical presentation of 
cryptosporidiosis varies from asymptomatic to deadly, leading to important economic losses due to growth retardation, reduced productivity and mortality $[9,10]$. Considering that an infected bovine calf can shed up to $1.1 \times 10^{8}$ oocysts per gram of feces at the peak of the infection, cattle (and very likely wild ruminants) are significant contributors of environmental Cryptosporidium oocysts [11, 12], causing water-borne [13-15] and foodborne $[16,17]$ diarrhea outbreaks in humans worldwide. The worldwide annual excretion of Cryptosporidium spp. oocysts by livestock has been calculated to be $3.2 \times 10^{23}$ [18], with cattle being the host species causing most environmental contamination. Cattle are able to carry different species including $C$. hominis which implies an associated significant public health risk [19]. In addition, Cryptosporidium oocysts are infective at the time they are passed in feces and are highly resilient to a wide range of environmental factors including disinfection and water treatment processes. Moreover, low infection doses are sufficient to cause disease in suitable hosts, e.g. 10-100 oocysts are described to provoke diarrhea in humans [20, 21].

Over the past few decades, a major subject of debate and controversy in the epidemiology of Cryptosporidium is whether, and to what extent, domestic and wildlife species may act as natural reservoirs of human cryptosporidiosis $[22,23]$. This is principally due to the fact that the genus Cryptosporidium encompasses nearly 40 valid species with marked differences in host range, among which over 10 (mainly C. hominis, C. parvum and C. meleagridis) have been reported in humans [24] with a variety of genotypes being zoonotic $[1,22,25]$. The public health significance of animal cryptosporidiosis varies greatly depending on factors such as geographical variation in prevalence and genotype distribution, seasonality, load of environmental contamination with oocysts and access to surface waters intended for human consumption or recreation $[9,26]$. In particular, genotyping data from epidemiological surveys conducted globally indicate that infected calves are the major reservoir for zoonotic C. parvum in many areas [26, 27], with lambs, kids and foals being potential additional sources of $C$. parvum infection for humans in some areas of the world [28-31]. Pigs are only sporadically infected with zoonotic Cryptosporidium species and are therefore considered minor contributors to the zoonotic transmission of cryptosporidiosis in humans [32]. Adult livestock typically harbor low level and asymptomatic infections but are epidemiologically important as cryptic carriers of the parasite, enabling re-infections at the herd level. Little is known of the molecular epidemiology and transmission cycles of cryptosporidiosis in wild ungulates. However, recent surveys have revealed the presence of C. parvum in wild hoofed species including the American mustang (Equus ferus caballus) [33], Scottish roe deer (Capreolus capreolus) and red deer (Cervus elaphus) [34], and Spanish wild boars (Sus scrofa scrofa) [35], which may represent a threat to water quality and public health [34].

In the present study, we conducted a systematic review of publications on the prevalence of Cryptosporidium infections and Cryptosporidium species distribution in domestic and wild ungulates in order to ascertain the extent to which hoofed animals should be considered as relevant reservoirs of human infection.

\section{Methods}

\section{Search strategy}

To evaluate the prevalence of Cryptosporidium infection in hoofed animals, we performed a comprehensive review of literatures (full text or abstracts) published online. English databases including PubMed, Scopus, Science Direct and Cochran were searched for publications related to Cryptosporidium infection of animals worldwide, from 1984 to 2016 . We used the following $\mathrm{MeSH}$ terms alone or in combination: "Cryptosporidium" or "cryptosporidiosis" and "prevalence" and "livestock" or "cattle" or "buffaloes" or "sheep" or "pigs" or "camels" or "alpacas" or "horses" or "ruminants" or "wildlife". To identify additional published articles, we used the PubMed option of "related articles" and checked the reference lists of the original and review articles. The more agricultural and veterinary focused database $\mathrm{CAB}$ abstracts was searched using the following search terms: "Cryptosporidium" or "cryptosporidiosis" and "prevalence" and "cattle" or "cows" or "calves" or "buffaloes" or "sheep" or "lambs" or "goats" or "kids" or "camels" or "alpacas" or "crias" or "llamas" or "pigs" or "piglets" or "horses" or "foals" or "deer" or "fawns" or "farm animals" or "ruminants" or "livestock" or "wildlife". A protocol for the literature review was devised (Fig. 1) in accordance with the PRISMA guidelines [36] (Additional file 1: Table S1).

\section{Inclusion and exclusion criteria}

As part of the eligibility for inclusion, titles that suggested the topic Cryptosporidium in domestic and wild hoofed animals were selected. The abstracts from the selected reference titles were reviewed by two independent reviewers to determine if the studies met the inclusion criteria and, if so, the entire articles were reviewed in full. If more than one report was published from the same study, only one was included. Exclusion criteria included studies only on human cryptosporidiosis or case reports. Studies on epidemiology of Cryptosporidium spp. in groups unrelated to hoofed animals, or studies presenting overall prevalence estimates, where samples were collected from the ground, and data from each animal 


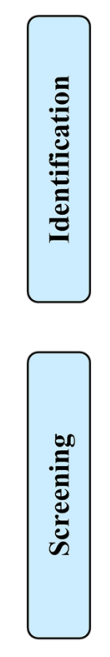

Records identified through database searching [Pubmed, Scopus, CAB abstracts and Google Scholar] $(n=14970)$
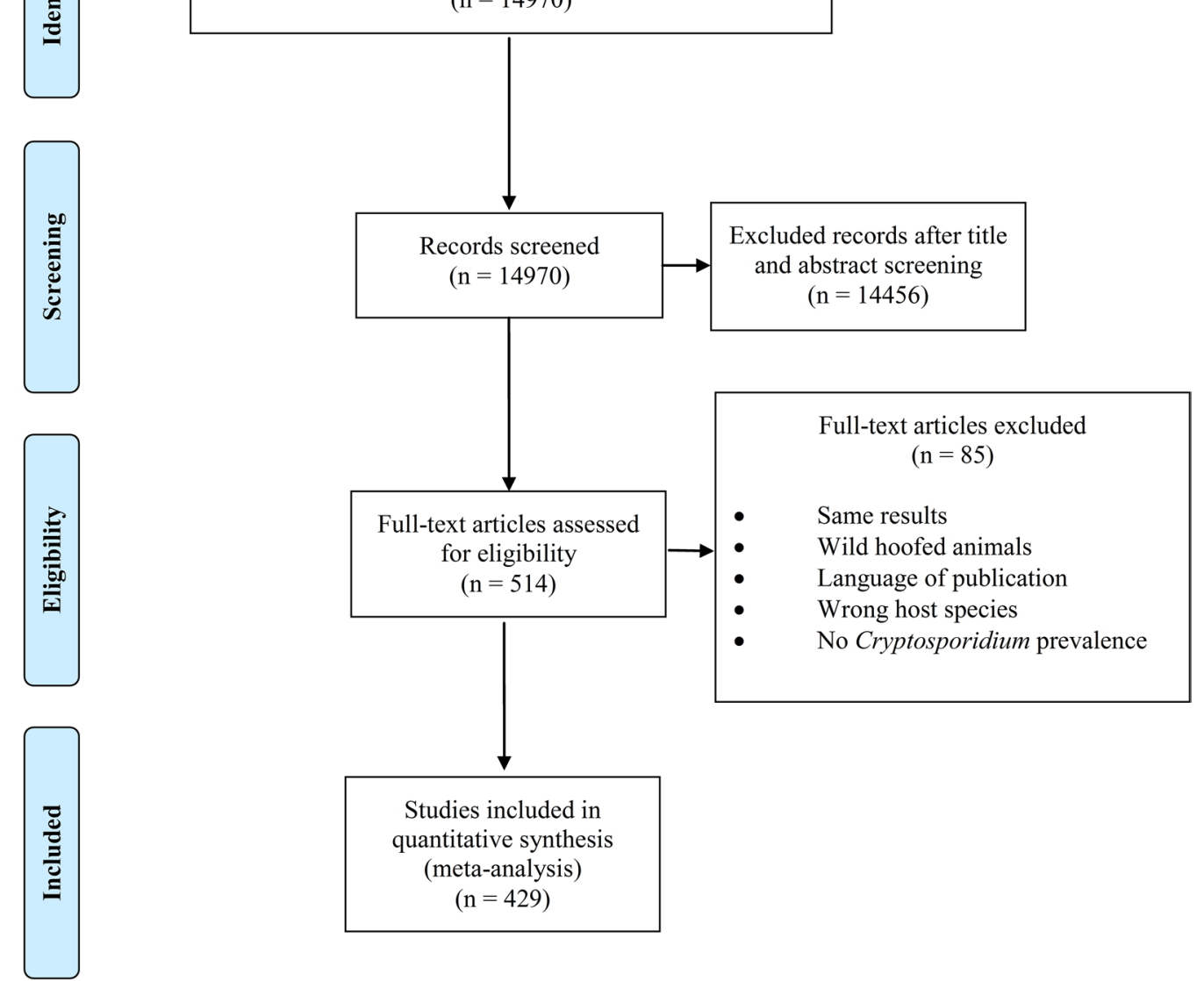

Fig. 1 Flow diagram describing the paper selection process according to PRISMA guidelines

were not independently retrievable, were also excluded. The language of data collection was limited to English. In order to provide contemporaneous and representative estimates, studies were excluded if they presented data collected prior to 1984. On several occasions, we contacted the authors for the collection of raw data.

\section{Data extraction and tabulation}

A data extraction form was used to collect the following data from each study: first author, year of publication, location of study, period of study, host species, age range, clinical signs (diarrhoeic versus non-diarrhoeic), population nature (e.g. domestic, captive or wild), total number of fecal samples, utilized detection method (conventional microscopy, CM; immunofluorescence antibody test, IFA; enzyme-linked immunosorbent assay, ELISA; immunochromatographic test, ICT; quantitative latex agglutination, QLAT; and polymerase chain reaction, PCR), number of Cryptosporidium-positive samples and identity of Cryptosporidium species and genotypes.

\section{Retrieving sequences and phylogenetic analyses}

To examine the genetic relationships among Cryptosporidium spp. (C. hominis, C. felis, C. parvum, $C$. erinacei, C. xiaoi, C. ryanae, C. scrofarum, C. muris, C. andersoni, C. ubiquitum, C. bovis and C. suis) in ungulates, a phylogenetic tree was constructed using the program Splits Tree v.4.0 based on the NeighborNet method and Median-Joining analysis of sequences 
of the $18 S$ rRNA gene [37]. For this purpose, the sequences of the $18 S$ rRNA gene of these Cryptosporidium spp. were retrieved from the GenBank database in the FASTA format. These sequences were initially obtained from various herbivores, including cattle, buffaloes, yaks, camels, goats, sheep and deer, as well as pigs.
Meta-analysis

A meta-analysis was performed for studies describing Cryptosporidium infection prevalence in domestic animals that are common in many parts of the world, i.e. cattle, sheep, goats, buffaloes, horses and pigs. This analysis was performed to enhance knowledge on the potential role of livestock in zoonotic Cryptosporidium

Table 1 Summarized Cryptosporidium prevalence data for major domestic farmed animals. Data for wild populations of the given species not included (see for full datasets and other host species in Additional file 2: Table S2)

\begin{tabular}{|c|c|c|c|c|c|}
\hline Host species & Region & No. of studies & Utilized diagnostic methods & $\begin{array}{l}\text { Retrieved minimum } \\
\text { prevalence (\%) }\end{array}$ & $\begin{array}{l}\text { Retrieved } \\
\text { maximum } \\
\text { prevalence (\%) }\end{array}$ \\
\hline \multirow[t]{5}{*}{ Buffalo (Bubalus bubalis) } & Africa & 6 & $C M, P C R$ & $1.3(\mathrm{CM})$ & $52.0(\mathrm{CM})$ \\
\hline & Asia & 16 & $C M, I C T, P C R$ & $3.6(\mathrm{CM})$ & $50.0(\mathrm{CM})$ \\
\hline & Australia & 2 & PCR & $13.1(\mathrm{PCR})$ & $30.0(\mathrm{PCR})$ \\
\hline & Europe & 1 & ELISA & 14.7 (ELISA) & \\
\hline & South America & 2 & $C M, P C R$ & 9.4 (CM) & $48.2(\mathrm{PCR})$ \\
\hline \multirow[t]{7}{*}{ Cattle (Bos taurus) } & Africa & 29 & CM, ELISA, PCR & $0.5(\mathrm{CM})$ & 86.7 (CM) \\
\hline & Asia & 74 & $C M, I C T, I F A, P C R$ & $1.5(\mathrm{CM})$ & 93.0 (CM) \\
\hline & Australia & 7 & $C M, I F A, P C R$ & 3.6 (IFA) & 73.5 (PCR) \\
\hline & Europe & 60 & CM, ELISA, ICT, IFA, PCR, QLAT & $0.0(\mathrm{CM})$ & 71.7 (CM) \\
\hline & New Zealand & 5 & CM, IFA & 2.6 (IFA) & $21.2(\mathrm{CM})$ \\
\hline & North America & 29 & $C M, I F A, P C R$ & 1.1 (IFA) & 78.0 (CM) \\
\hline & South America & 11 & $C M, I C T, P C R$ & $3.0(\mathrm{CM})$ & $56.1(\mathrm{CM})$ \\
\hline \multirow[t]{6}{*}{ Goat (Capra hircus) } & Africa & 10 & CM, ELISA & $0.0(\mathrm{CM})$ & 76.5 (ELISA) \\
\hline & Asia & 15 & $C M, I C T$, IFA & 0.0 (IFA) & 42.9 (CM) \\
\hline & Australia & 1 & $P C R$ & 4.4 (PCR) & \\
\hline & Europe & 22 & CM, ELISA, IFA & $0.0(\mathrm{CM})$ & 93.0 (IFA) \\
\hline & North America & 3 & $\mathrm{CM}$ & 20.0 (CM) & 72.5 (CM) \\
\hline & South America & 3 & $\mathrm{CM}$ & $4.8(\mathrm{CM})$ & $100(\mathrm{CM})$ \\
\hline \multirow[t]{6}{*}{ Sheep (Ovis aries) } & Africa & 10 & CM, ELISA, PCR & $1.3(\mathrm{CM})$ & 41.8 (ELISA) \\
\hline & Asia & 17 & CM, ELISA, ICT, PCR & $1.8(\mathrm{CM})$ & $66.6(\mathrm{CM})$ \\
\hline & Australia & 7 & PCR & $2.2(\mathrm{PCR})$ & 81.3 (PCR) \\
\hline & Europe & 22 & CM, IFA, ELISA & $1.4(\mathrm{CM})$ & $100.0(\mathrm{CM})$ \\
\hline & North America & 9 & $C M, I F A, P C R$ & $20.0(\mathrm{CM})$ & 77.4 (PCR) \\
\hline & South America & 5 & $C M, P C R$ & $0.0(\mathrm{CM})$ & 25.0 (PCR) \\
\hline \multirow[t]{6}{*}{ Pig (Sus scrofa) } & Africa & 5 & CM, ELISA, IFA, PCR & 13.6 (CM) & 44.9 (ELISA) \\
\hline & Asia & 13 & $C M, I F A, P C R$ & 0.4 (IFA) & 55.8 (PCR) \\
\hline & Australia & 3 & $C M, P C R$ & 0.3 (CM) & 22.1 (PCR) \\
\hline & Europe & 13 & $C M, I F A, P C R$ & $0.1(\mathrm{CM})$ & 40.9 (IFA) \\
\hline & North America & 6 & CM, IFA & 2.8 (ns) & 19.6 (CM) \\
\hline & South America & 3 & $C M, P C R$ & $0.0(\mathrm{CM})$ & $2.2(\mathrm{PCR})$ \\
\hline \multirow[t]{6}{*}{ Horse (Equus caballus) } & Africa & 3 & $C M, P C R$ & $0.0(\mathrm{CM})$ & 2.9 (PCR) \\
\hline & Asia & 7 & $C M, P C R$ & 2.7 (PCR) & $37.0(\mathrm{CM})$ \\
\hline & Europe & 10 & CM, ELISA, IFA, PCR & 3.4 (PCR) & 25.0 (IFA) \\
\hline & New Zealand & 2 & $\mathrm{CM}$ & $18.0(\mathrm{CM})$ & 83.3 (CM) \\
\hline & North America & 6 & $C M, I F A, P C R$ & $0.0\left(I F A / P C R^{a}\right)$ & 17.0 (IFA) \\
\hline & South America & 7 & CM & $0.0(\mathrm{CM})$ & $100.0(\mathrm{CM})$ \\
\hline
\end{tabular}

a Multiple studies revealed the same prevalence data

Abbreviation: $\mathrm{ns}$, not stated 


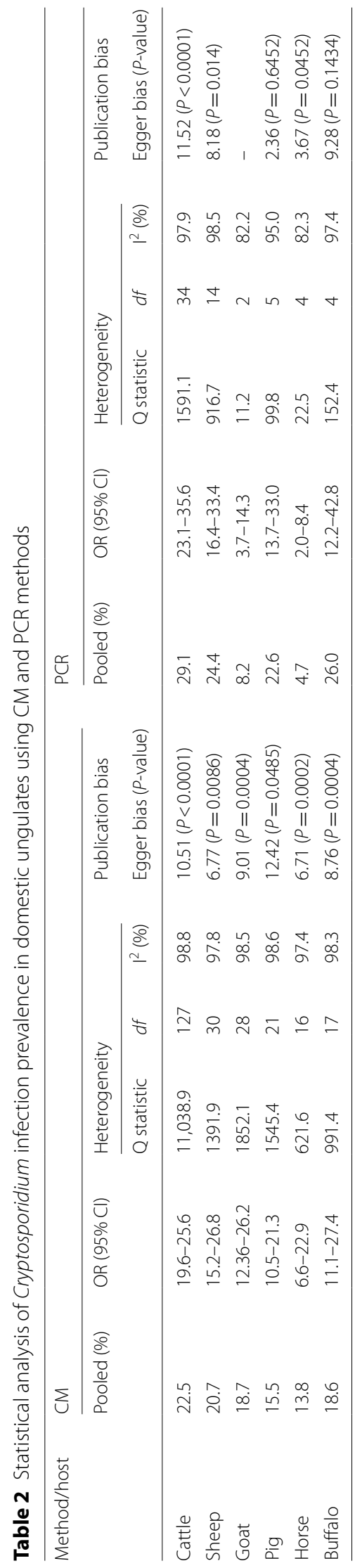


Proportion meta-analysis plot [random effects]

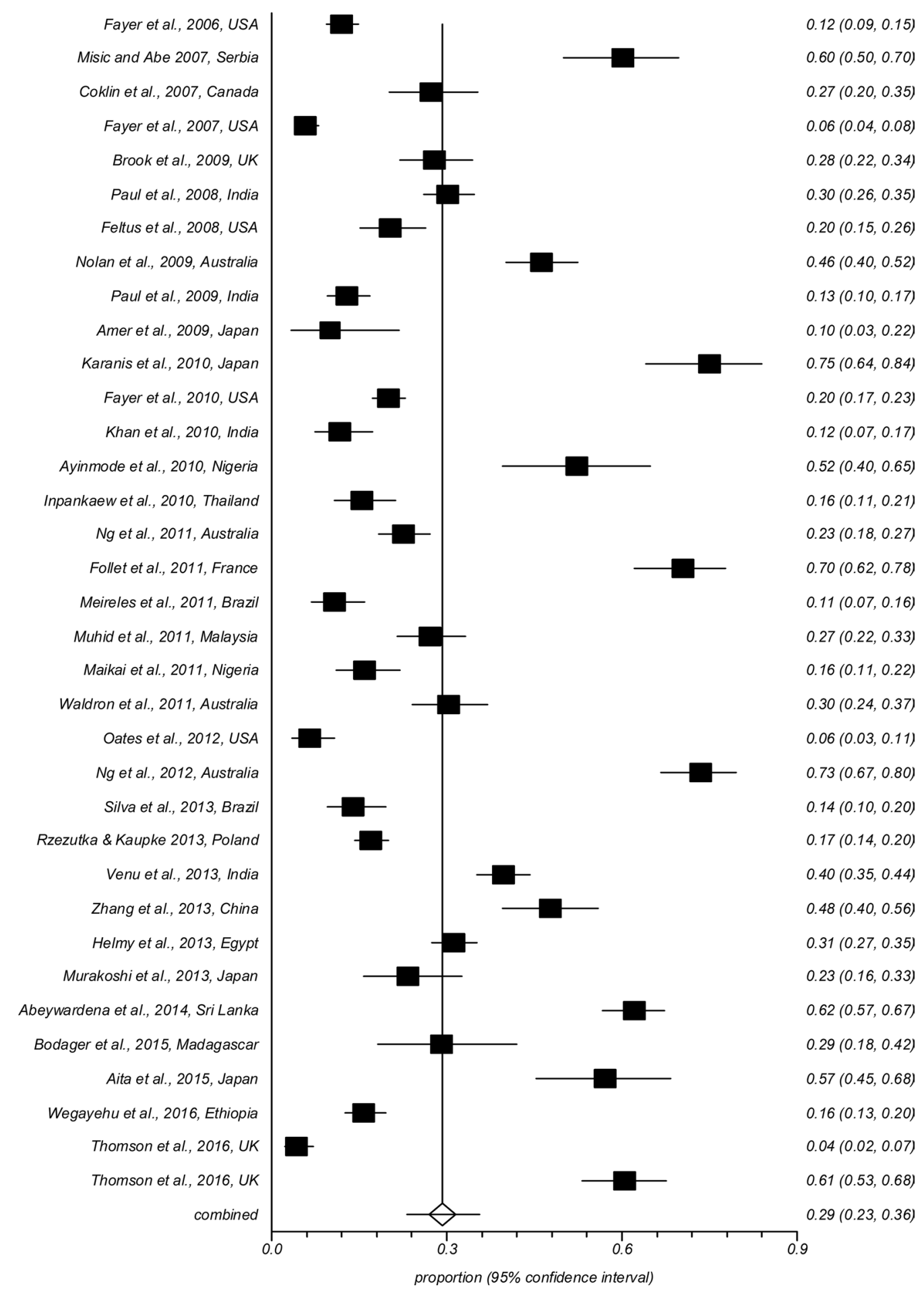

Fig. 2 Forest plot of prevalence of Cryptosporidium spp. infection in cattle using molecular methods (first author, year and country) 
Proportion meta-analysis plot [random effects]

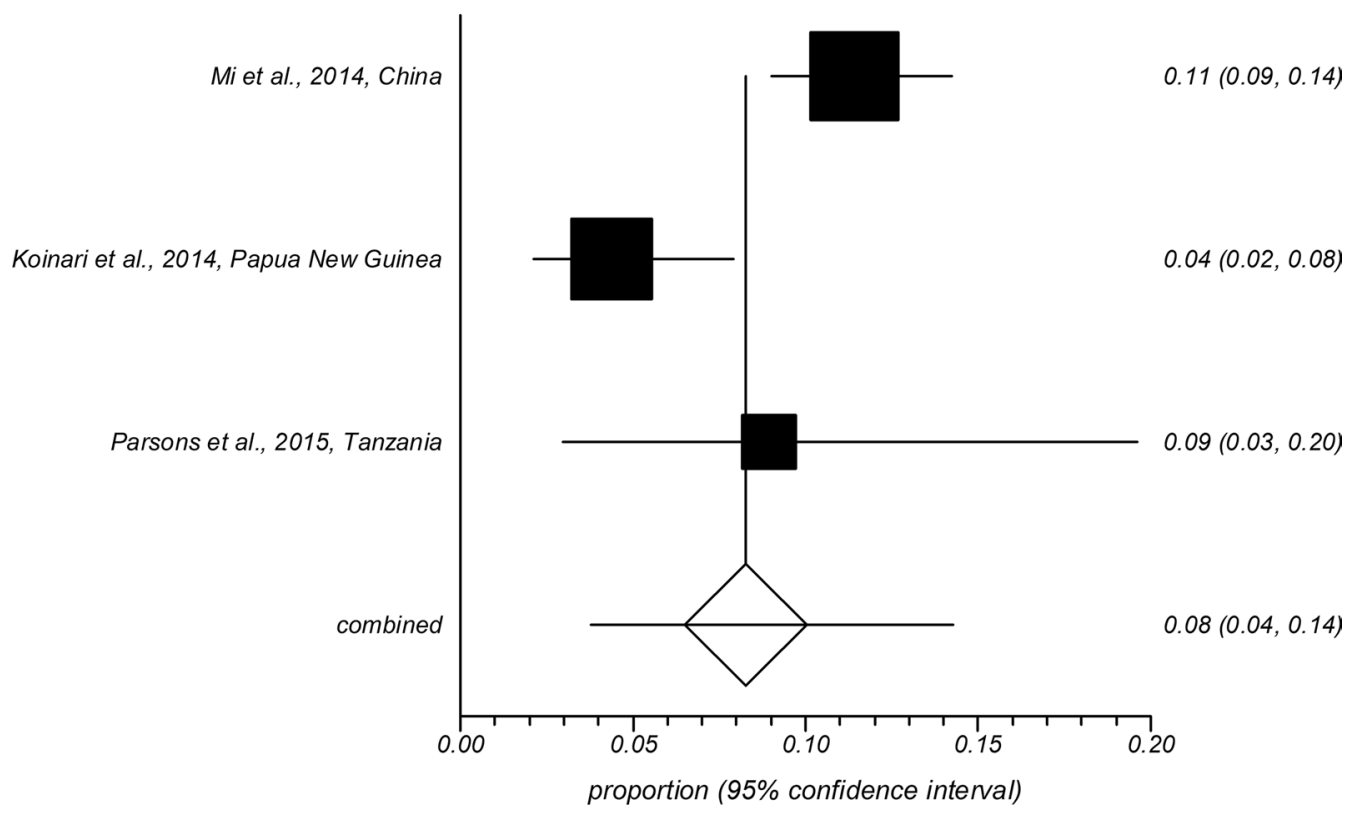

Fig. 3 Forest plot of prevalence of Cryptosporidium spp. infection in goats using molecular methods (first author, year and country)

transmission since these animals feature a close contact to humans. The pooled prevalence of Cryptosporidium infection as well as its $95 \%$ confidence interval (CI) was calculated for each study. A forest plot was generated to display the summarized results and heterogeneity among the included studies. To ensure comparable sensitivity of tests used in analyzed studies, only results from studies based on PCR as a diagnostic method were included. Studies using PCR methods only for molecular Cryptosporidium species/genotype identification but utilizing alternative diagnostic methods to determine prevalence were not included. The heterogeneity was expected in advance and statistical analyses including $I^{2}$ and Cochrane's $Q$ test (with a significance level of $P<0.1$ ) were used to quantify these variations. The meta-analysis considering the random effects model [38] was performed using the Stats Direct statistical software (http:// www.statsdirect.com).

\section{Results}

The initial database search retrieved 14,970 publications. The screening of these records enabled us to exclude 14,456 studies due to not meeting the inclusion criteria. Altogether, 514 studies were retained for further investigation. During the secondary assessment of these papers, another 85 were excluded because of one of the following reasons: other host species including wild hoofed animals; report of the same results as another paper published by the same author; and language of publication (e.g. Chinese, Spanish, etc.). Papers evaluating cryptosporidiosis in camels, yaks, donkeys, alpacas and llamas were excluded in the secondary analysis of data, as the meta-analysis focused on Cryptosporidium infection in cattle, sheep, goats, pigs, buffaloes and horses. Eventually, 429 studies which evaluated Cryptosporidium infection during three decades met our eligibility criteria and were retained for analysis (Fig. 1).

Different diagnostic procedures were used for the detection of Cryptosporidium oocysts to a varying extent in the different studies. The included publications featured CM examination $(n=371)$, IFA $(n=107)$, ELISA $(n=25)$, ICT $(n=9)$, quantitative latex agglutination (QLAT) $(n=1)$ and polymerase chain reaction (PCR) $(n=99)$ (Additional file 2: Table S2).

In total, 196,638 stool samples from Artiodactyla and Perissodactyla ungulates were evaluated, of which 37,206 (18.9\%) subjects were positive for Cryptosporidium infection. Among the 196,638 stool samples, 90,744 were associated with the domestic hoofed animals (including camels, yaks, donkeys, alpacas and llamas), displaying a Cryptosporidium infection prevalence of $13.6 \%$ $(n=12,377)$ (Table 1 and Additional file 2: Table S2).

All subsequent analyses included only the studies that focused on Cryptosporidium infection in cattle, sheep, 
goats, pigs, buffaloes and horses $(n=429)$. Among them, 201 provided data on cattle, 66 on sheep, 55 on goats, 39 on pigs, 37 on horses and 28 on buffaloes (Additional file 2: Table S2).

A total of 105,894 samples from 245 studies on common livestock, defined as cattle, sheep, goats, pigs, horses and buffaloes, were examined for Cryptosporidium infection, with 24,829 (23.4\%) being positive for Cryptosporidium spp. using CM and PCR methods. Most of the studies were conducted on cattle $(n=163)$ and sheep $(n=46)$.

The pooled prevalence rates using the CM method were $22.5 \%$ (95\% CI: 19.6-25.6\%), 20.7\% (95\% CI: $15.2-$ 26.8\%), $18.7 \%$ (95\% CI: $12.36-26.2 \%), 15.5 \%$ (95\% CI: 10.5-21.3\%), 13.8\% (95\% CI: 6.6-22.9\%) and 18.6\% (95\% CI: 11.1-27.4\%) for cattle, sheep, goats, pigs, horses and buffaloes, respectively (Table 2 ). The pooled prevalence rates using the PCR method were 29.1\% (95\% CI:
23.1-35.6\%), 24.4\% (95\% CI: 16.4-33.4\%), 8.2\% (95\% CI: $3.7-14.3 \%$ ), $22.6 \%$ (95\% CI: $13.7-33 \%$ ), 4.7\% (95\% CI: 2-8.4\%) and 26.0\% (95\% CI: 12.2-42.8\%) for cattle, sheep, goats, pigs, horses and buffaloes, respectively (Table 2). Analysis of available data by regions (continents and New Zealand) showed a moderate geographical variation of observed prevalence (Table 1). Although diagnostic tests varied among regions, the observed prevalence mostly fell within the $5-30 \%$ range (Table 2 ). Regarding cattle, a considerably lower maximum prevalence was seen in New Zealand compared to other regions. Cryptosporidium prevalence in goat tended to be lower in Asia; however, only one study was available for Australia. For sheep it was the highest in the regions with most intensive sheep production, i.e. Australia, Europe and North America (Table 1). Cryptosporidium prevalence in pigs was the highest in Asia, Africa and Europe. In horses,

\section{Proportion meta-analysis plot [random effects]}

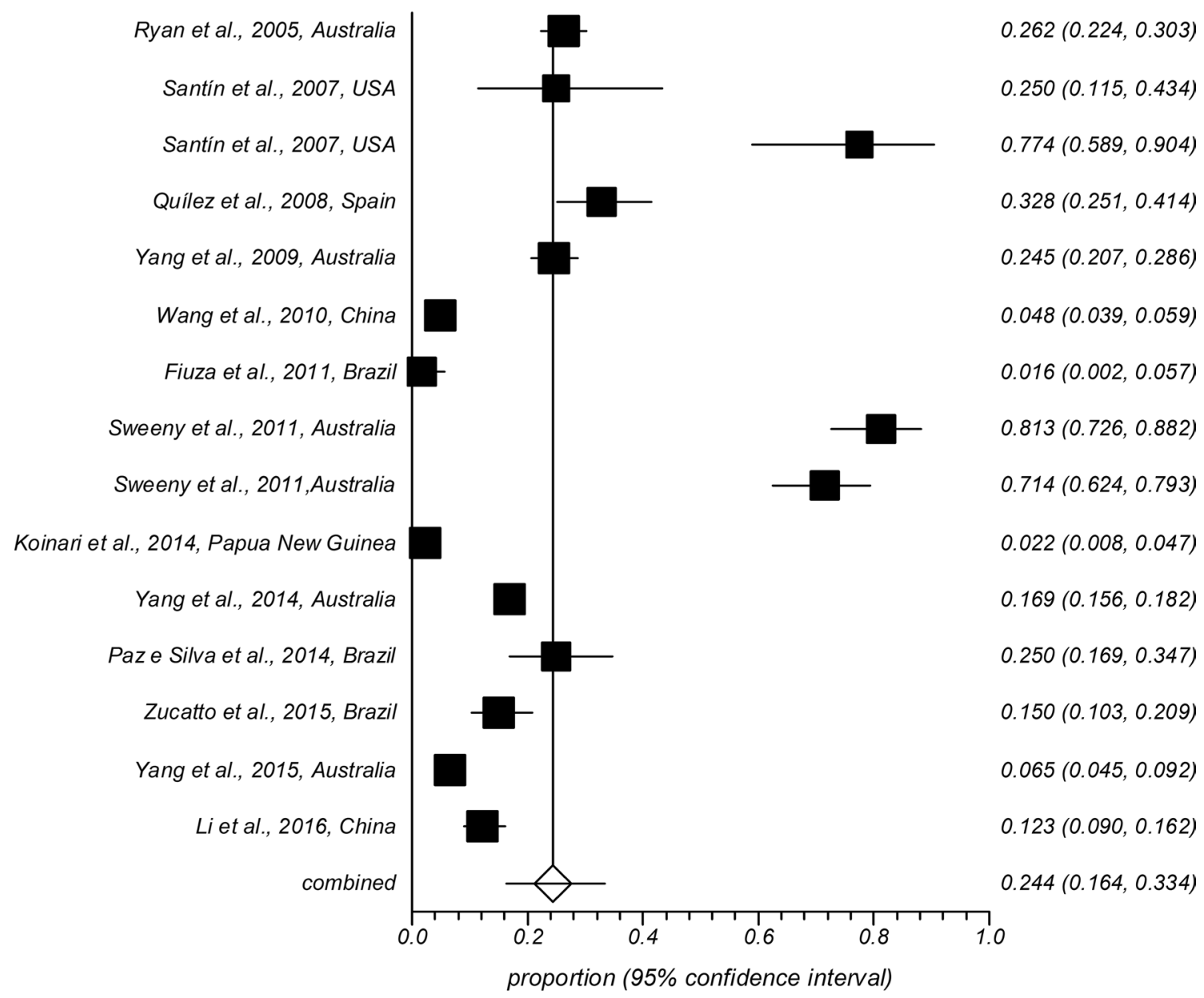

Fig. 4 Forest plot of prevalence of Cryptosporidium spp. infection in sheep using molecular methods (first author, year and country) 
studies in South America reported the highest Cryptosporidium prevalence.

The forest plot diagrams of prevalence of Cryptosporidium infection in domestic hoofed animals derived from studies using a PCR method are shown in Figs. 2, $3,4,5,6,7$. As forest plots show, there is a considerable variation of study numbers and observed prevalence in a given host species within each defined geographical region, even if only studies based on PCR methodology are included. Considering a wider range of studies, i.e. studies that use either CM or PCR (Table 2), cattle are most commonly infected globally while horses feature the lowest Cryptosporidium prevalence.

The highest and lowest prevalence rate of Cryptosporidium infection in domestic hoofed animals was observed in America (26\%) and Africa (14\%) continents, respectively (Table 3, Fig. 8). Among 53 countries with data, Canada (60\%) showed the highest infection rate whereas China, Thailand and Germany (8\%) had the lowest infection rate (Table 3, Fig. 8).

The distribution of Cryptosporidium species/genotypes by host and geographical region is summarized in Table 4 . Cryptosporidium parvum (monoinfections 4172/10,583; 39.4\%) and C. andersoni (monoinfections 1992/10,583; $18.8 \%$ ) were the most commonly detected Cryptosporidium species (Table 4). A phylogenetic network was constructed based on sequences of Cryptosporidium spp.
(Fig. 9) using the Neighbor-Net method. On the basis of this phylogenetic analysis, 10 clades (I, II, III, IV, V, VI, VII, VIII, IX and X) containing 12 Cryptosporidium spp. were identified (Fig. 9). Interestingly, C. andersoni and C. muris were placed together in Clade I, and C. xiaoi and C. bovis were both placed in Clade III. It further demonstrated a pairwise sister relationship between clades III and IV (clustering C. xiaoi, C. bovis, and C. ryanae), VI and VII (containing C. ubiquitum and C. suis) and VIII and IX (containing C. hominis and C. erinacei), respectively. Interestingly, the result of the phylogenetic analysis indicated that clades II (C. scrofarum), III (C. bovis and C. xiaoi) and IV (C. ryanae) could have originated from a common ancestor. The distribution of Cryptosporidium spp. in a wide range of domestic and wild ungulates is presented in Table 4 . The $C$. parvum is the most common genotype in cattle $(54.1 \%)$, goats $(42.1 \%)$ and horses $(40.2 \%)$, followed by C. ryanae in buffaloes (66.6\%), C. suis in pigs (54.1\%), and C.xiaoi in sheep (48.9\%). In terms of transmission dynamics and clinical importance of zoonotic Cryptosporidium spp., C. hominis, C. parvum, C. andersoni, C. bovis and C. ubiquitum were identified in sheep/goats, cattle/goats/horses/pigs/ sheep, cattle/camels/sheep/yaks, buffaloes/cattle/sheep/ pigs/red deer and alpacas/buffaloes/cattle/goats/impalas/ sheep/red deers, respectively (Table 4).

\section{Proportion meta-analysis plot [random effects]}

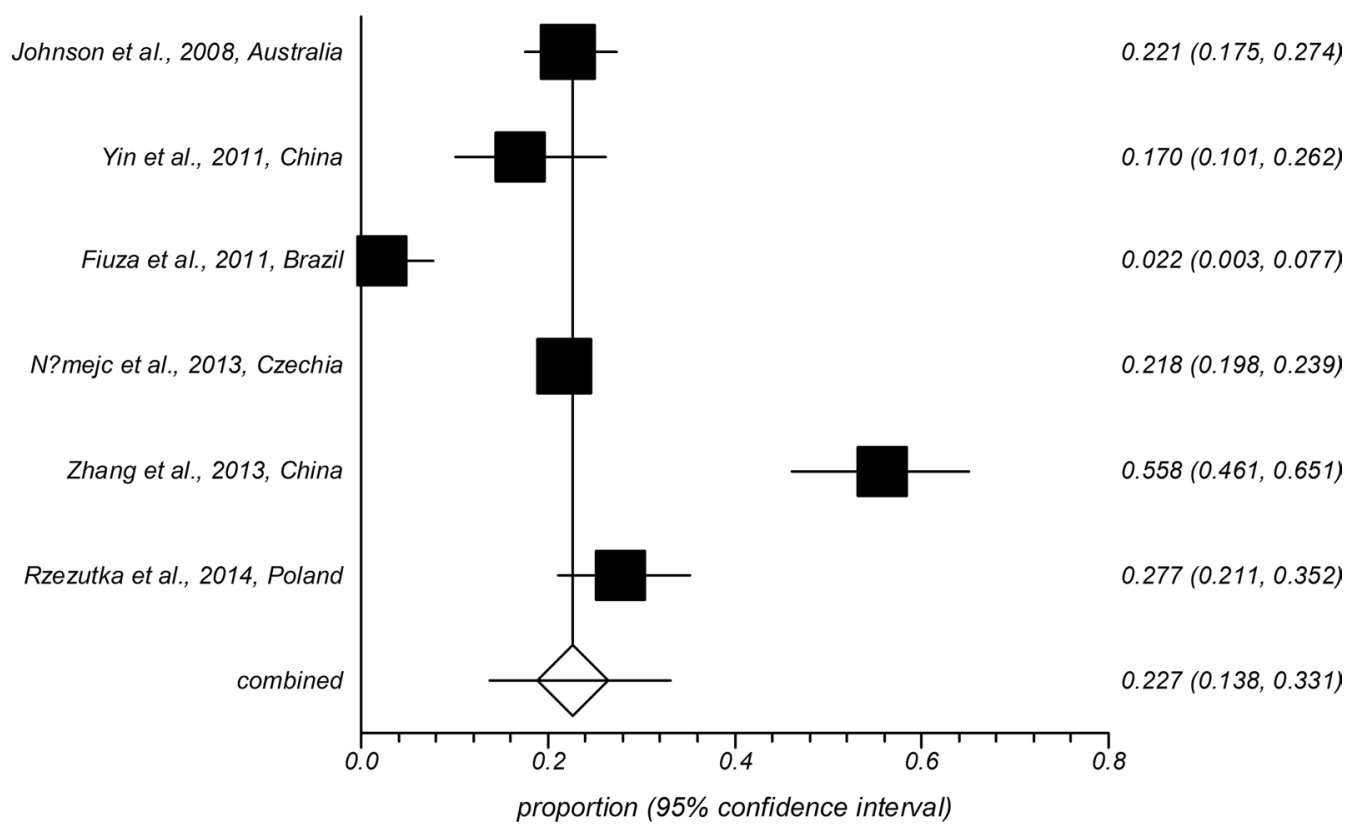

Fig. 5 Forest plot of prevalence of Cryptosporidium spp. infection in pigs using molecular methods (first author, year and country) 


\section{Proportion meta-analysis plot [random effects]}

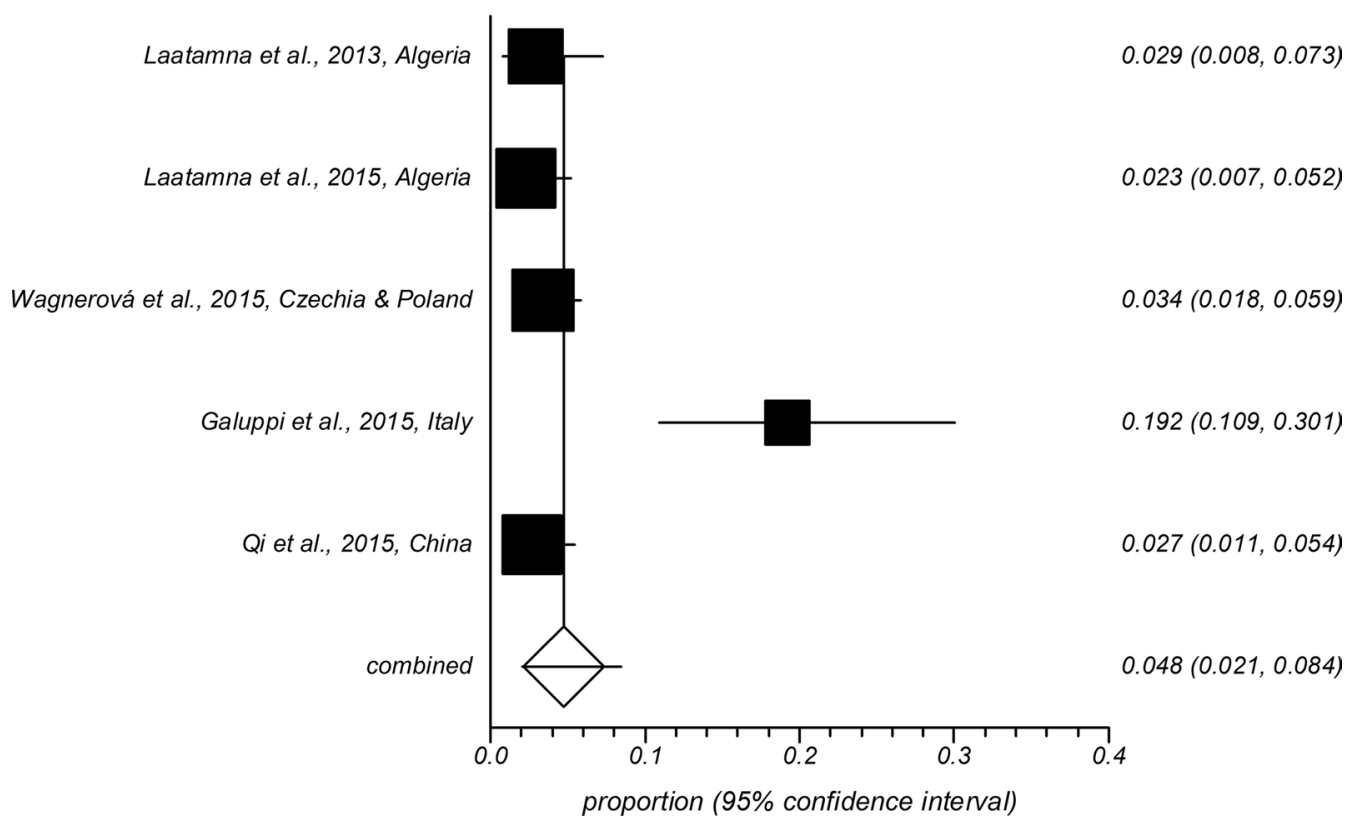

Fig. 6 Forest plot of prevalence of Cryptosporidium spp. infection in horses using molecular methods (first author, year and country)

\section{Proportion meta-analysis plot [random effects]}

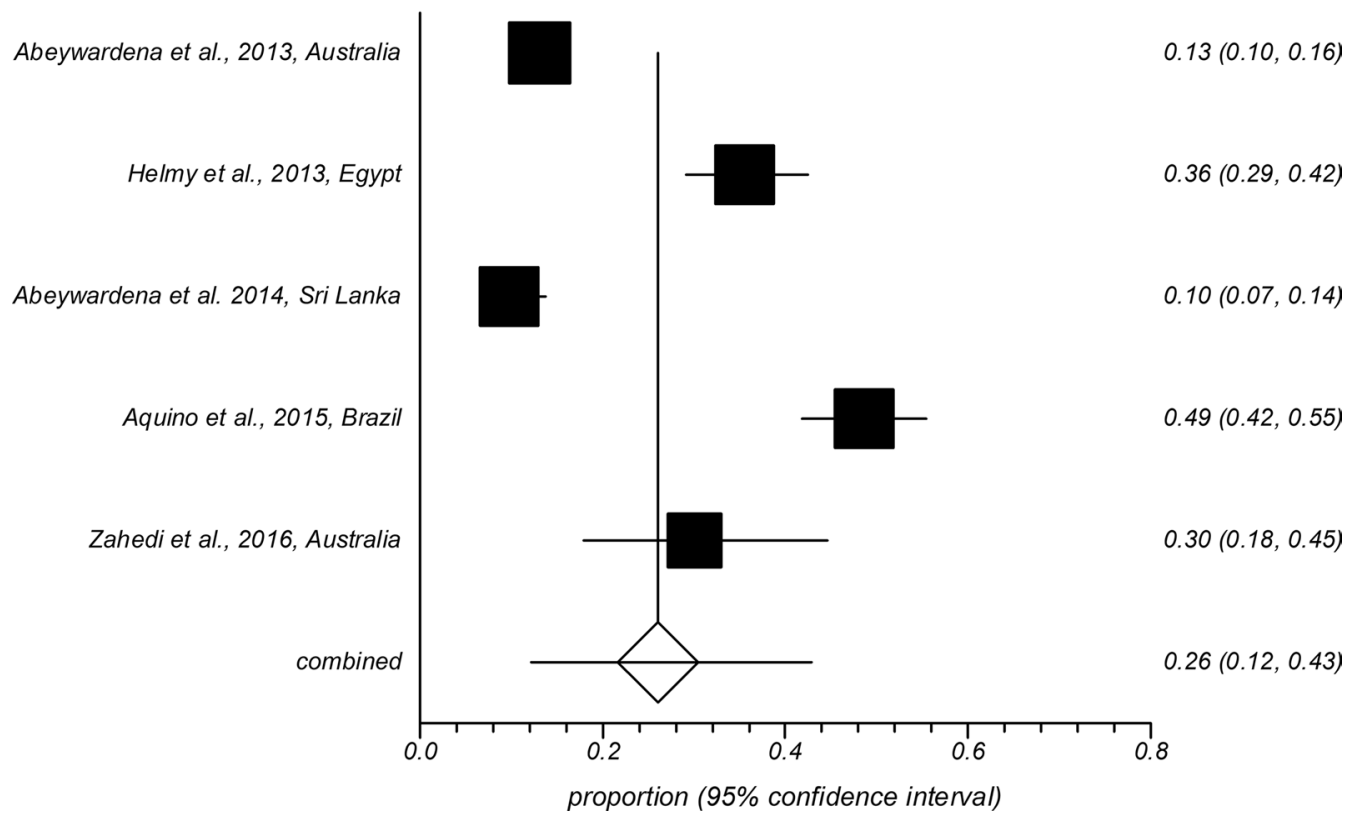

Fig. 7 Forest plot of prevalence of Cryptosporidium spp. infection in buffaloes using molecular methods (first author, year and country) 
Table 3 The prevalence of Cryptosporidium infection in terrestrial ungulates (cattle, sheep, goat, pig, horse and buffalo) using conventional microscopic methods. Data are presented separately by continent and country

\begin{tabular}{|c|c|c|}
\hline Continent & Country & Prevalence, pooled proportion (95\% CI) (\%) \\
\hline \multirow[t]{10}{*}{ Africa (43 studies; 17,424 samples) } & Egypt & $10(4.44-19.32)$ \\
\hline & Ethiopia & $17(7.15-30.13)$ \\
\hline & Ghana & $29^{\mathrm{a}}$ \\
\hline & Kenya & $15(10.72-21.30)$ \\
\hline & Malawi & $18(10.48-28.78)$ \\
\hline & Nigeria & $17(13.07-22.33)$ \\
\hline & South Africa & $0.5^{\mathrm{a}}$ \\
\hline & Tanzania & $11(1.59-29.29)$ \\
\hline & Tunisia & $14(2.09-44.93)$ \\
\hline & Total prevalence in Africa: 14 (11.12-18.31) & \\
\hline \multirow[t]{9}{*}{ America (37 studies; 15,860 samples) } & Argentina & $25(18.83-33.58)$ \\
\hline & Brazil & $16(5.82-30.23)$ \\
\hline & Canada & $60(23.32-91.14)$ \\
\hline & Chile & $56^{\mathrm{a}}$ \\
\hline & Costa Rica & $11^{\mathrm{a}}$ \\
\hline & Mexico & $41(31.81-52.23)$ \\
\hline & Trinidad & $32(6.47-67.24)$ \\
\hline & USA & $11(2.84-24.39)$ \\
\hline & Total prevalence in America: 26 (18.41-34.67) & \\
\hline \multirow[t]{16}{*}{ Asia (90 studies; 37,458 samples) } & Bangladesh & $9(2.93-20.36)$ \\
\hline & China & $8(5.62-12.95)$ \\
\hline & India & $21(16.02-28.47)$ \\
\hline & Iran & $16(11.96-20.68)$ \\
\hline & Iraq & $17(11.36-25.23)$ \\
\hline & Japan & $24(0.02-72.52)$ \\
\hline & Malaysia & $24(8.43-46.55)$ \\
\hline & Myanmar & $56^{\mathrm{a}}$ \\
\hline & Nepal & $35(28.81-43.45)$ \\
\hline & Pakistan & $16(9.05-25.96)$ \\
\hline & South Korea & $17(11.53-23.57)$ \\
\hline & Sri Lanka & $28^{\mathrm{a}}$ \\
\hline & Taiwan & $35(32.44-38.15)$ \\
\hline & Thailand & $8(3.08-17.41)$ \\
\hline & Vietnam & $18^{\mathrm{a}}$ \\
\hline & Total prevalence in Asia: 17 (14.94-20.30) & \\
\hline \multirow[t]{3}{*}{ Australia (4 studies; 923 samples) } & Australia & $23(0.00-71.85)$ \\
\hline & New Zealand & $20(15.42-25.92)$ \\
\hline & Total prevalence in Australia: 21 (7.28-40.02) & \\
\hline \multirow[t]{10}{*}{ Europe (71 studies, 34,229 samples) } & Austria & $11^{\mathrm{a}}$ \\
\hline & Czech Republic & $17(9.87-27.11)$ \\
\hline & Denmark & $33(14.90-55.60)$ \\
\hline & France & $17(2.56-41.08)$ \\
\hline & Germany & $8(3.62-48.31)$ \\
\hline & Greece & $17(9.87-27.11)$ \\
\hline & Ireland & $23(3.84-52.25)$ \\
\hline & Netherlands & $60^{\mathrm{a}}$ \\
\hline & Poland & $11(3.62-21.85)$ \\
\hline & Portugal & $17^{\mathrm{a}}$ \\
\hline
\end{tabular}


Table 3 (continued)

\begin{tabular}{lll}
\hline Continent & Country & Prevalence, pooled proportion (95\% CI) (\%) \\
\hline & Romania & $21(15.02-27.97)$ \\
& Serbia & $40(31.95-49.48)$ \\
& Spain & $29(19.80-39.75)$ \\
& Sweden & $8^{\text {a }}$ \\
& Switzerland & $55^{\text {a }}$ \\
& Turkey & $34(19.82-50.61)$ \\
& UK & $34(0.59-85.50)$ \\
\hline
\end{tabular}

a One study was performed in these countries

\section{Discussion}

In this systematic review and meta-analysis, we found that $18.9 \%$ of the overall populations of the investigated ungulate species were infected with Cryptosporidium spp. Our study showed that although the prevalence of Cryptosporidium infection was higher in ungulates of the Cetartiodactyla than in Perissodactyla, the prevalence in the latter was not negligible and needs to be considered in terms of pathogen transmission and cycling. From the data collected and summarized on wild animals (as included in Table 4, and Additional file 2: Table S2), it is obvious that sylvatic cycles play a major role in Cryptosporidium transmission. Wild terrestrial ungulates are likely serving as important reservoir for the parasite, and certainly the infection of livestock and humans may occur by contact to wildlife feces. For meta-analysis, worldwide Cryptosporidium prevalence and species/genotype identity common livestock species have been scrutinized. Overall, Cryptosporidium prevalence in farmed animals is the highest in the Americas and Europe (Table 3) which could be attributed to the intensive farm animal production in these regions. More specifically, considering domestic farm animals, the pooled prevalence of equine Cryptosporidium infection was $4.7 \%$, compared to the pooled prevalence of $29.1 \%, 26.0 \%, 24.4 \%, 22.6 \%$ and $8.2 \%$ in cattle, buffaloes, sheep, pigs and goats, respectively. Regarding the number of studies published for the different geographical regions, our analysis does not support under investigation of certain regions (e.g. Asia) as cause of a detection bias. This reinforces the suggestion that animal production intensity affects the prevalence of Cryptosporidium spp. Concentrated animal feeding operations (CAFOs) are most common in cattle and pigs. For example, in the USA, in 2002 more than $71 \%$ of all produced beef were derived from operations holding more than 5000 heads of cattle each. It is known that CAFOs pose a major problem due to the high amounts of manure that are released to the environment, facilitating potential pathogen transmission to humans, wildlife and other agricultural operations [39]. Furthermore, pathogen transmission within a CAFO seems much more likely than in more extensive farming systems. Accordingly, a high prevalence of Cryptosporidium was observed in animals from countries with many CAFO operations, especially in studies in Asia and Europe, with both regions harboring the majority of the commercial pig raising industry [40]. High prevalences in pigs in Africa may be attributed to the opposite effect of extensive farming with high exposure to environmental contamination. Other host animals displaying a high prevalence, such as buffaloes and sheep, are also generally kept in larger groups on commercial operations. The comparatively low prevalence rates in equines and goats may potentially result from smaller animal groups and free-range nature of the animal management.

Between wild and domestic animals, it appears that Cryptosporidium prevalence is lower in wild populations than in farmed populations in the same host species. For example, Zahedi et al. [41] reported Cryptosporidium infection rates of $30 \%$ in farmed buffalo but $12 \%$ in wild buffalo. This suggests that animal density and confinement to the same (contaminated) environment facilitate Cryptosporidium transmission in domestic animals, and there is no clear host species disposition in terms of general susceptibility to infection with the genus Cryptosporidium despite the observed variation in Cryptosporidium infection rates among host species (Table 4).

Cryptosporidiosis in ungulates, especially ruminants, has several economic and health implications. Cryptosporidiosis in neonatal calves can lead to profuse watery diarrhea, loss of appetite, lethargy, dehydration and even death, thus may require costly treatments [42]. Moreover, as shown in sheep and goats, cryptosporidiosis can exhibit long-term effects on the growth of animals [43, 44]. Additionally, infected calves can shed over $1 \times 10^{10}$ oocysts each day, which can survive in the environments for months. The ingestion of very few oocysts can cause infection in susceptible hosts, including humans [23, 45]. 


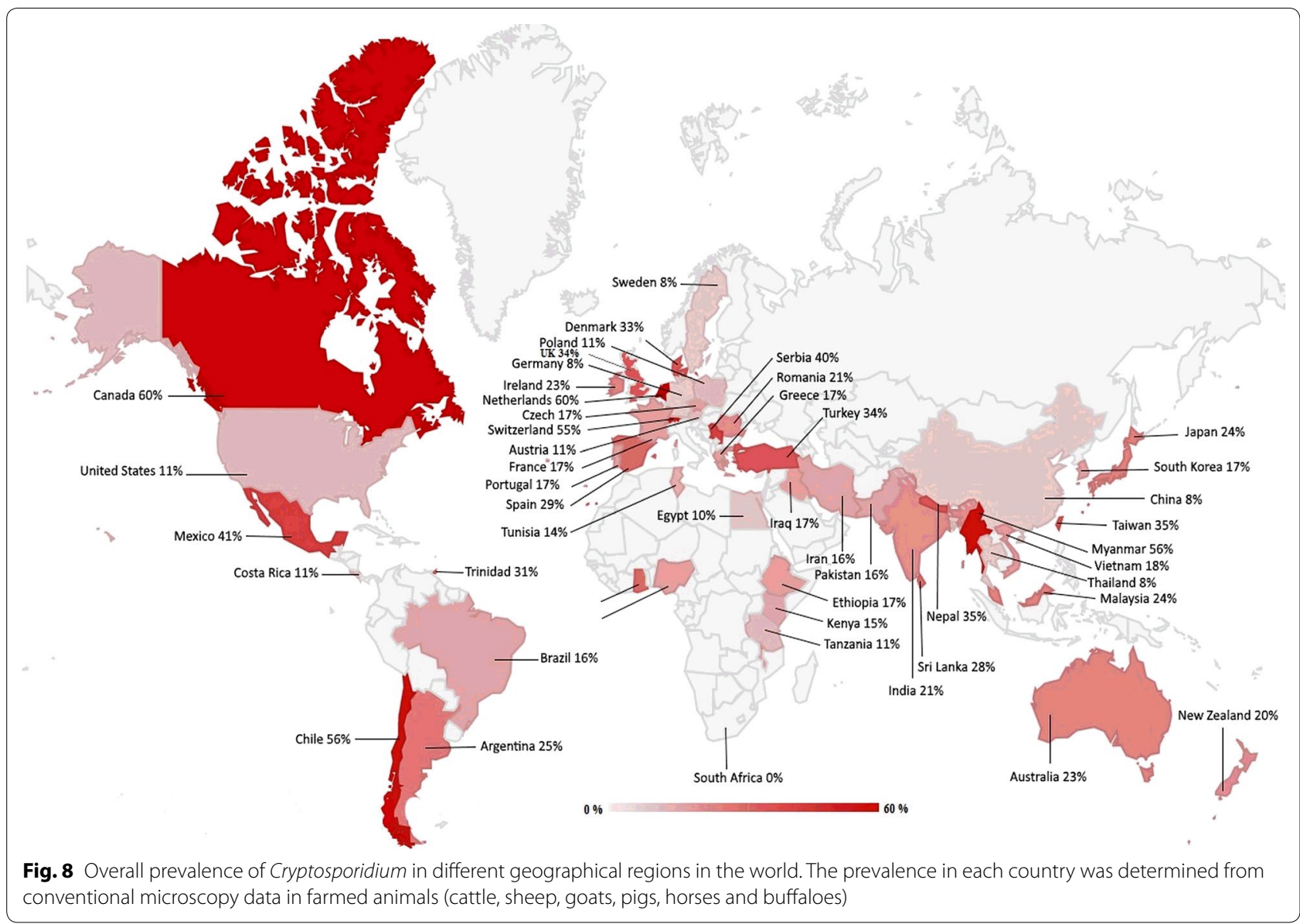

It has been shown that the median infection dose of $C$. parvum for humans range from below 10 to over 1000 oocysts [22]. Zoonotic transmission of Cryptosporidium spp. can easily occur seasonally from young animals such as bovine calves to humans, frequently as an occupational hazard [45, 46].

Nearly 40 Cryptosporidium species have been recognized based on molecular, morphological and biological characteristics of the parasites. Previous studies have shown that four major species are responsible for bovine cryptosporidiosis, namely C. parvum, C. andersoni, $C$. bovis and C. ryanae [1]. We showed that the most prevalent Cryptosporidium species in ungulates are $C$. parvum and C. andersoni, comprising $39.4 \%$ and $18.8 \%$ of detected parasites, respectively.

The data also suggest that some Cryptosporidium species are shared among ungulate hosts (Table 4). This indicates the occurrence of some inter-species transmission of Cryptosporidium spp. among ungulate species, making wildlife an important reservoir for infections in domestic animals. Currently, most data on the distribution of Cryptosporidium species and genotypes are available on domestic animal populations. Amazingly, there are clear differences in the distribution of Cryptosporidium species within the same host species among geographical regions. For example, studies from Ethiopia and Nigeria indicate that $C$. andersoni and $C$. bovis are the most prevalent species in cattle. In contrast, in countries with concentrated animal feeding operations (CAFO) such as Australia, Iran, Japan and New Zealand, as well as many European and North American countries, C. parvum is prevalent in cattle (Table 4). Similarly, alpacas in their region of origin are mostly infected with $C$. parvum and C. ubiquitum, while alpacas in the UK only tested positive for C. parvum (Table 4). Calves, lambs and goat kids in areas with more human activities can even have C. hominis infections $[19,41,47,48]$. Thus, it might be speculated that husbandry systems and contact to other livestock and humans strongly influence the distribution of Cryptosporidium species in an ungulate population.

Our meta-analysis had several limitations. We observed a substantial heterogeneity among the included studies. Heterogeneity in the meta-analyses of prevalence is not uncommon, and the random-effect 


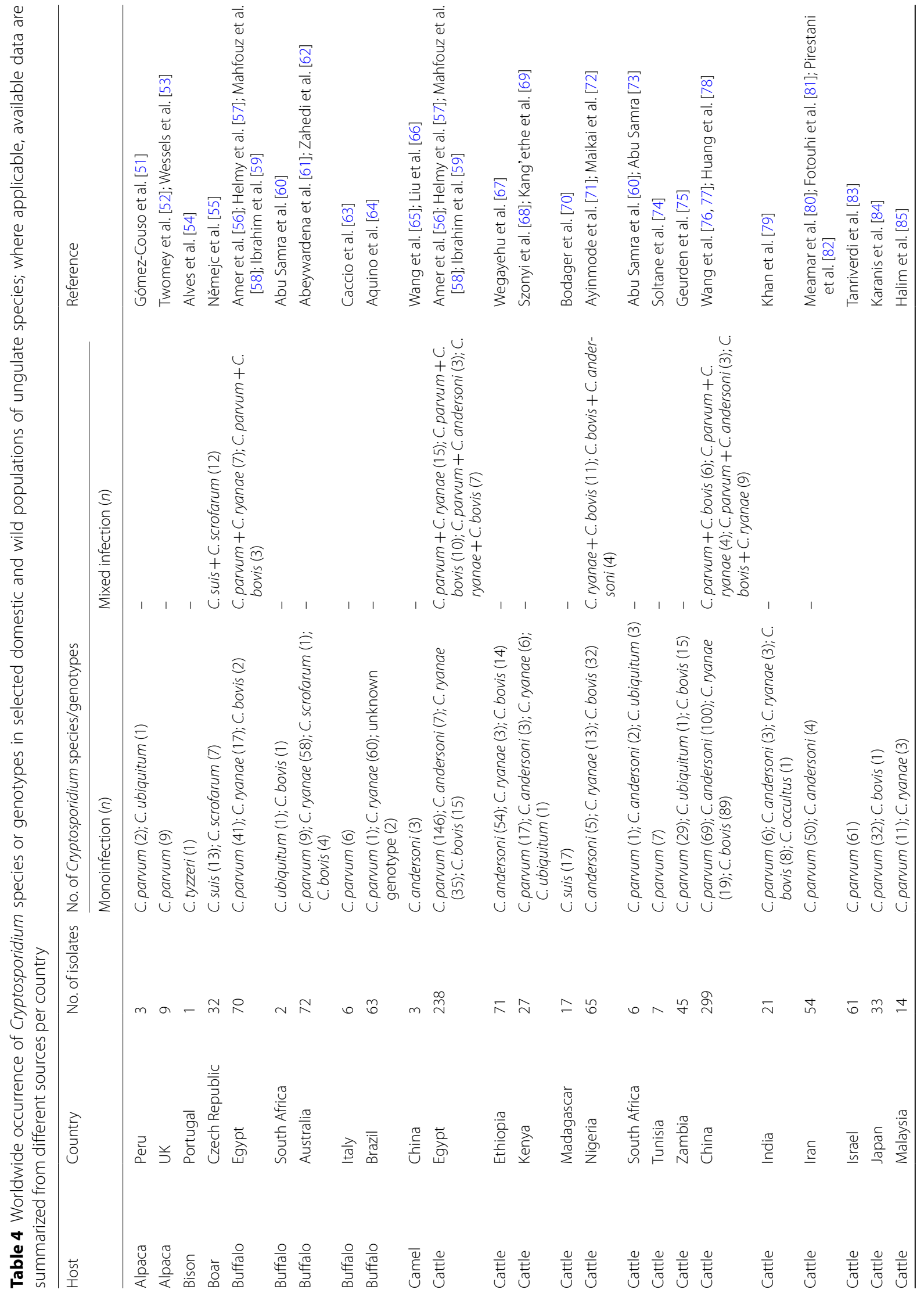




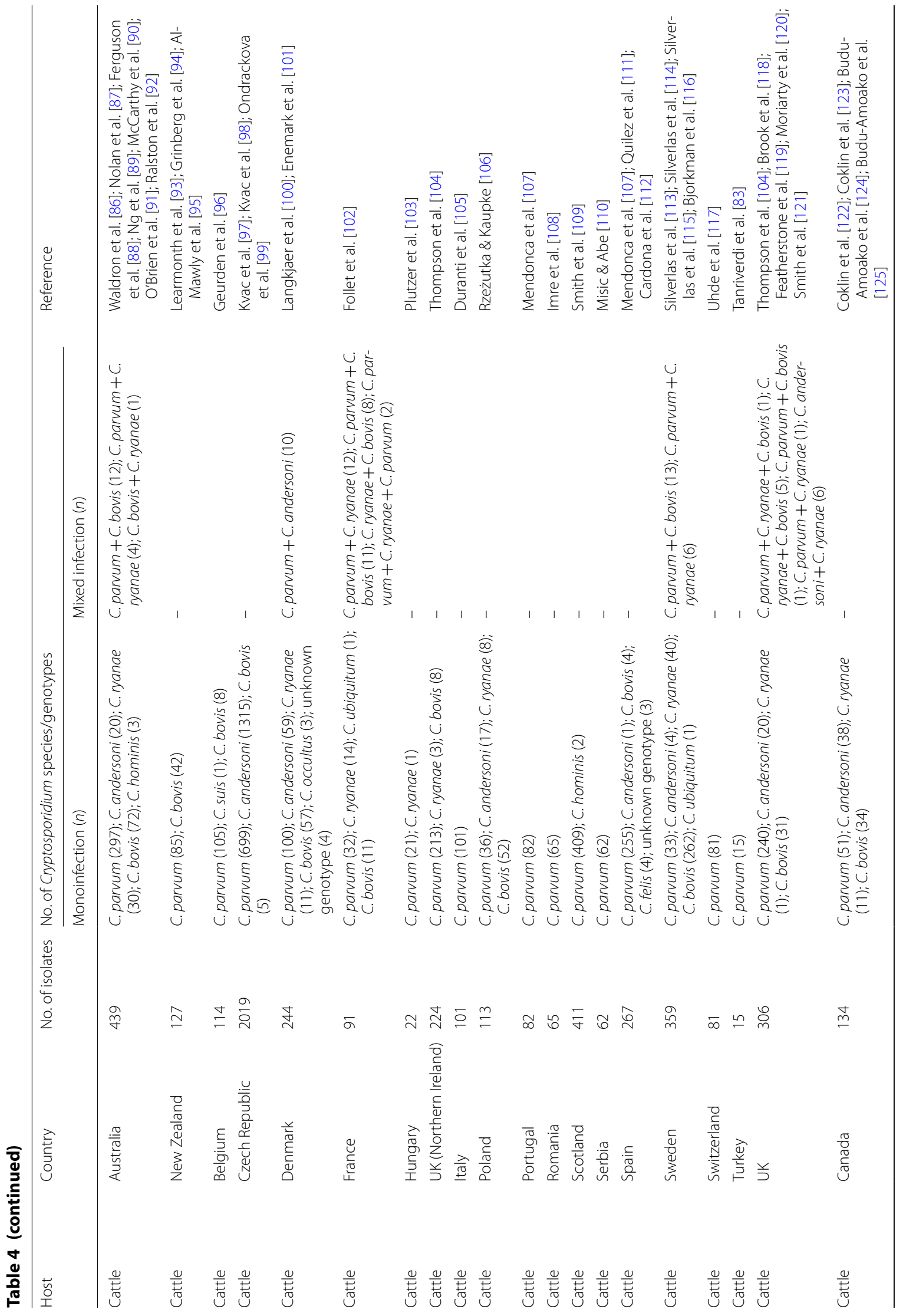




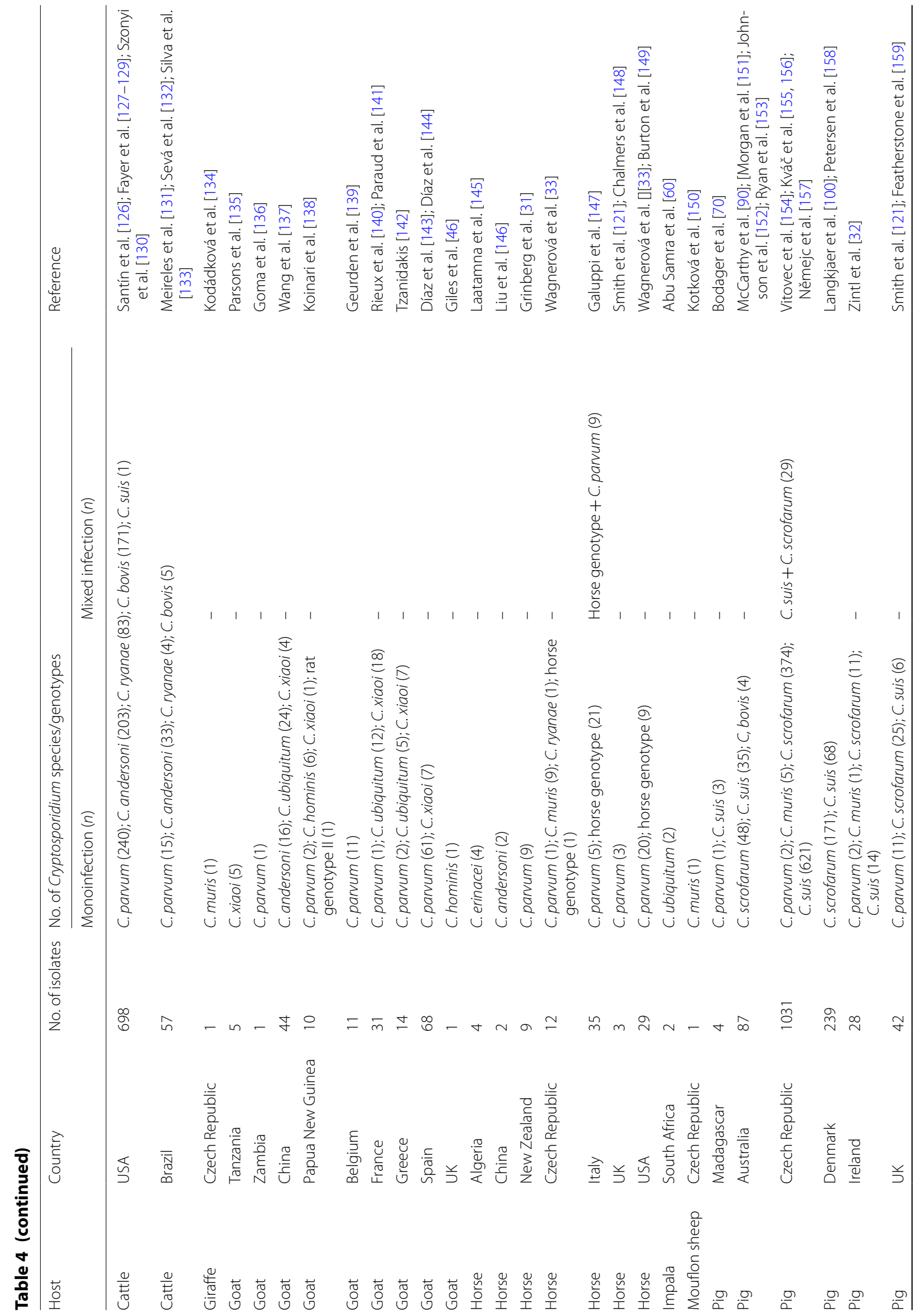




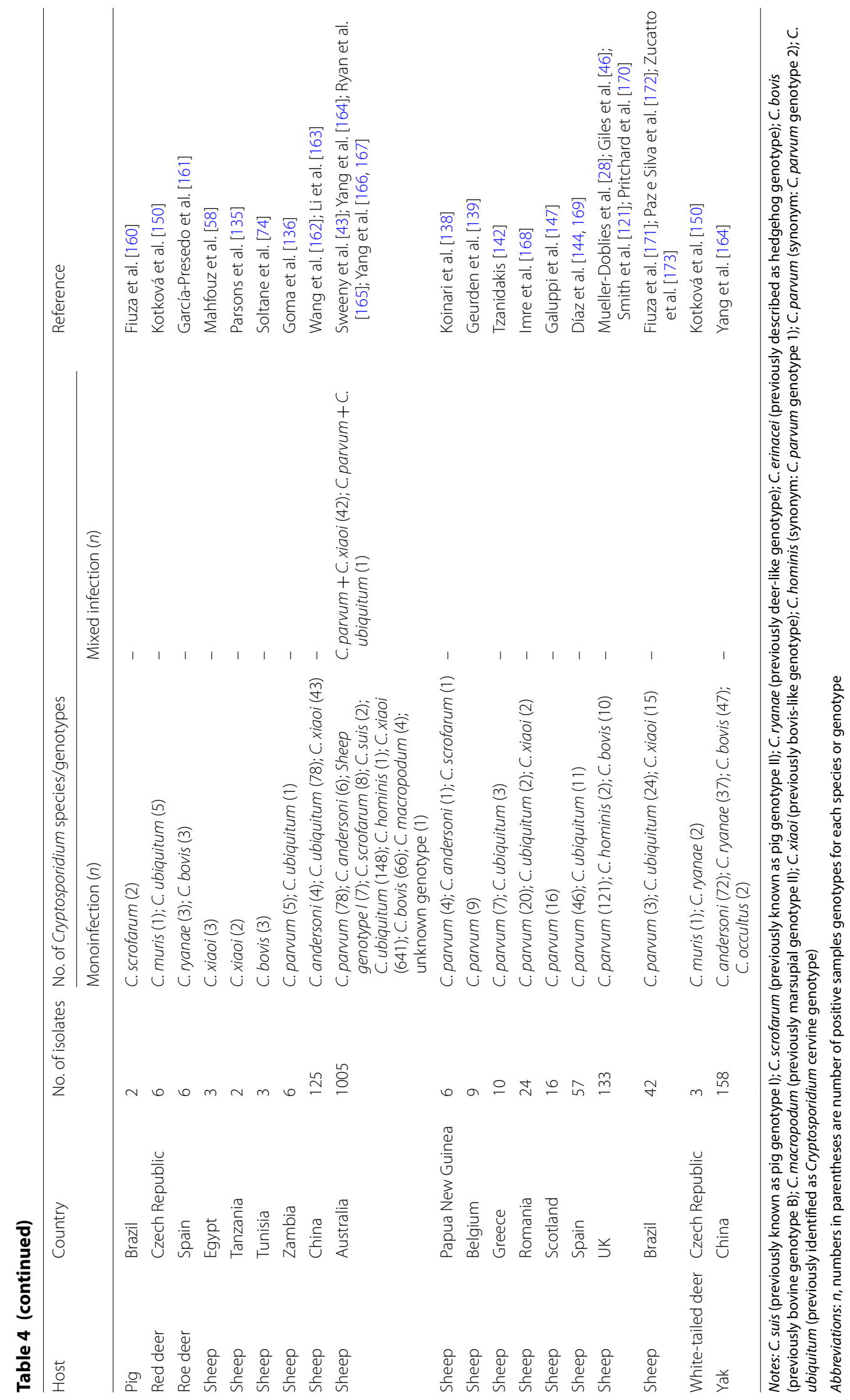


model implicitly incorporates some of the heterogeneity [49]. Nevertheless, we investigated several factors that can contribute to the observed heterogeneity. The diagnostic method used for the detection of Cryptosporidium infection was one of the main confounding variables. For example, the pooled prevalence of bovine Cryptosporidium infection was estimated $29.1 \%$ using PCR compared to $22.5 \%$ using conventional microscopy. This seems to indicate that molecular methods such as PCR are highly sensitive and specific for the detection of Cryptosporidium infection, but compared with conventional microscopic methods, they are more expensive and require a higher degree of expertise [50].

There are geographical differences in the estimated pooled prevalence of Cryptosporidium infection. The prevalence was highest in the continent of America, followed by Europe, Australia, Asia and Africa. Canada had the highest prevalence among countries. Study design, time of sampling, age of animals, and conditions of keeping animals are other factors that can contribute to the observed heterogeneity in cryptosporidiosis prevalence, in addition to the nature of animal management.

The outcome of our study is probably affected by the publication bias. Publication bias occurs when the results of studies affect the likelihood of their inclusion in the systematic review and meta-analysis [49]. Our systematic review was limited to studies published after 1984 in English. Moreover, many studies did not provide enough information to be included in the meta-analysis.

\section{Conclusions}

Results of the meta-analysis suggest that Cryptosporidium infection is highly prevalent in ungulates, especially ruminants. Geographical differences in Cryptosporidium prevalence and distribution of Cryptosporidium species are seen for most domestic ungulate hosts. These within-host-species differences could be partially attributed to differences in animal management among geographical regions. The highest prevalence in farmed ungulates occurs in America and Europe where CAFO is widely practiced. The major farm animal hosts of Cryptosporidium spp. appear to be cattle, buffalo, sheep and pigs. These farm animals are potent reservoirs for a variety of Cryptosporidium species. Cryptosporidium prevalence is also clearly higher in farmed animals than in wild ungulate populations. Inter-species transmission of Cryptosporidium spp. appears to be affected by contact with other host species (humans or other animals) and infection pressure (intensive farming), rendering the investigated ungulate hosts capable of propagating both zoonotic and nonzoonotic Cryptosporidium species.

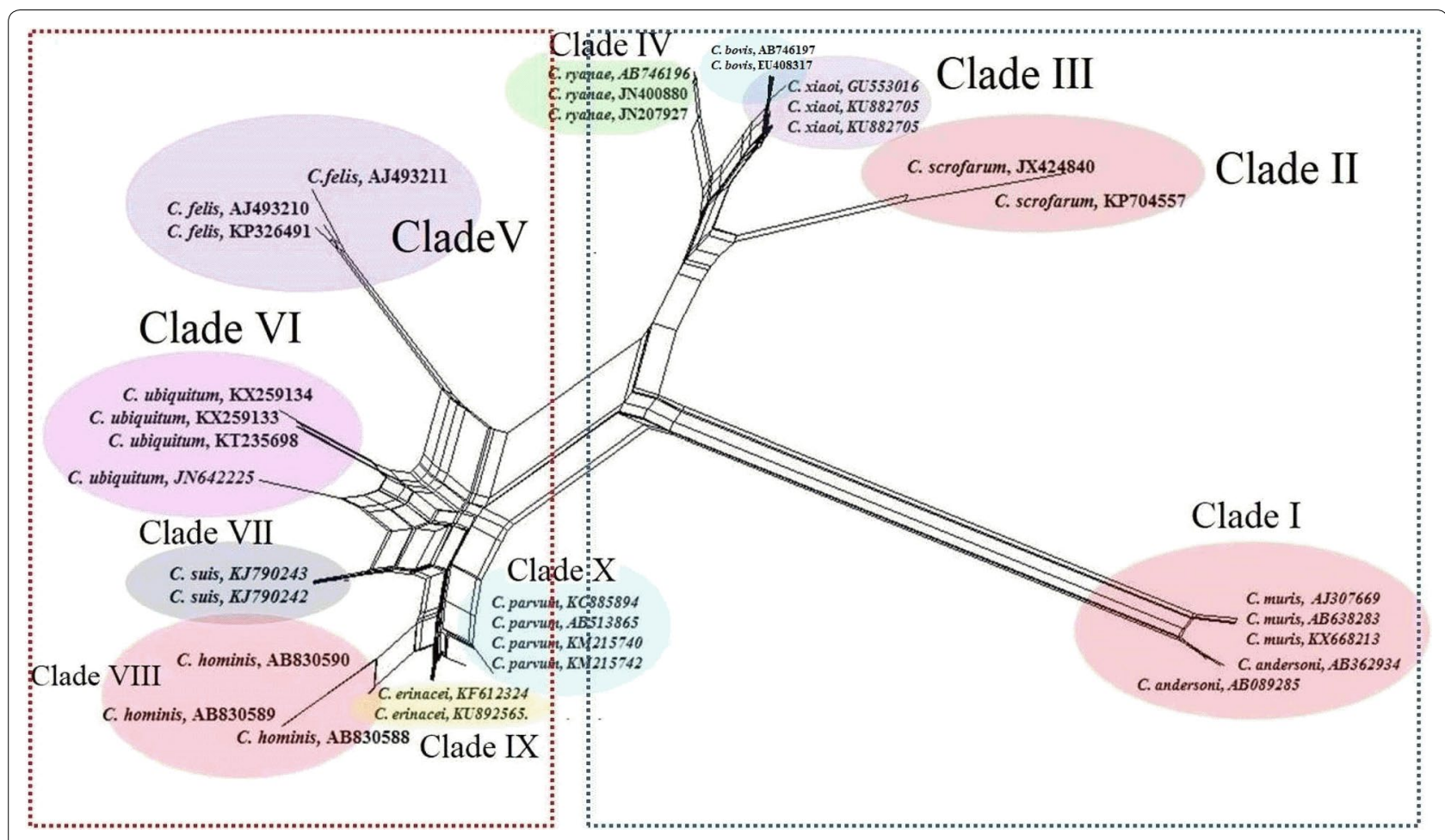

Fig. 9 The phylogeny of Cryptosporidium spp 


\section{Supplementary information}

Supplementary information accompanies this paper at https://doi. org/10.1186/s13071-019-3704-4.

Additional file 1: Table S1. PRISMA checklist.

Additional file 2: Table S2. Worldwide prevalence of Cryptosporidium spp. in herbivorous animals.

\section{Abbreviations}

CM: conventional microscopy; ELISA: enzyme-linked immunosorbent assay; ICT: immunochromatographic test; PCR: polymerase chain reaction; PRISMA: Preferred Reporting Items for Systematic Reviews and Meta-Analyses; QLAT: quantitative latex agglutination test.

\section{Acknowledgements}

We would like to thank Mr. F. Shahrivar and Dr. A.S. Pagheh for their assistance and kind help.

\section{Authors' contributions}

$\mathrm{KHN}, \mathrm{EH}, \mathrm{DC}$ and $\mathrm{LX}$ contributed to the design of the study. KHN, EA and AS conducted the systematic review of the literature and extracted data. EA, AS, $D C$ and $L X$ analyzed data and drafted the first version of the manuscript. EA, $D C, B B$ and $L X$ contributed to the interpretation of data and writing of the first draft. All authors read and approved the final manuscript.

\section{Funding}

The authors received no financial support for the research.

\section{Availability of data and materials}

Data supporting the conclusions of this article are included within the article and its additional files.

\section{Ethics approval and consent to participate}

Not applicable.

\section{Consent for publication}

Not applicable.

\section{Competing interests}

The authors declare that they have no competing interests.

\section{Author details}

${ }^{1}$ Iranshahr University of Medical Sciences, Iranshahr, Iran. ${ }^{2}$ Infectious and Tropical Diseases Research Center, Tabriz University of Medical Sciences, Tabriz, Iran. ${ }^{3}$ Parasitology Reference and Research Laboratory, National Centre for Microbiology, Carlos III Health Institute, Ctra Majadahonda-Pozuelo Km 2, 28220 Majadahonda, Madrid, Spain. ${ }^{4}$ Immunology Research Center, Tabriz University of Medical Sciences, Tabriz, Iran. ${ }^{5}$ Drug Applied Research Center, Tabriz University of Medical Sciences, Tabriz, Iran. ${ }^{6}$ Department of Veterinary Sciences, College of Agriculture and Natural Resources, University of Wyoming, Laramie, WY, USA. ${ }^{7}$ College of Veterinary Medicine, South China Agricultural University, Guangzhou, China.

Received: 9 May 2019 Accepted: 5 September 2019

Published online: 14 September 2019

\section{References}

1. Feng Y, Ryan UM, Xiao L. Genetic diversity and population structure of Cryptosporidium. Trends Parasitol. 2018;34:997-1011.

2. Khalil IA, Troeger C, Rao PC, Blacker BF, Brown A, Brewer TG, et al. Morbidity, mortality, and long-term consequences associated with diarrhoea from Cryptosporidium infection in children younger than 5 years: a meta-analysis study. Lancet Glob Health. 2018;6:e758-68.

3. Scallan E, Hoekstra RM, Angulo FJ, Tauxe RV, Widdowson M-A, Roy SL, et al. Foodborne illness acquired in the United States-major pathogens. Emerg Infect Dis. 2011;17:7-15.
4. DuPont HL. Persistent diarrhea: a clinical review. JAMA. 2016;315:2712-23.

5. Hatam-Nahavandi K, Mohebali M, Mahvi AH, Keshavarz H, Khanaliha K, Tarighi F, et al. Evaluation of Cryptosporidium oocyst and Giardia cyst removal efficiency from urban and slaughterhouse wastewater treatment plants and assessment of cyst viability in wastewater effluent samples from Tehran, Iran. J Water Reuse Desal. 2015;5:372-90.

6. Marcos LA, Gotuzzo E. Intestinal protozoan infections in the immunocompromised host. Curr Opin Infect Dis. 2013:26:295-301.

7. Cho YI, Han JI, Wang C, Cooper V, Schwartz K, Engelken T, et al. Case-control study of microbiological etiology associated with calf diarrhea. Vet Microbiol. 2013;166:375-85.

8. Meganck V, Hoflack G, Opsomer G. Advances in prevention and therapy of neonatal dairy calf diarrhoea: a systematical review with emphasis on colostrum management and fluid therapy. Acta Vet Scand. 2014:56:75.

9. Thompson RA, Palmer CS, O'Handley R. The public health and clinical significance of Giardia and Cryptosporidium in domestic animals. Vet J. 2008;177:18-25.

10. Santin M. Clinical and subclinical infections with Cryptosporidium in animals. N Z Vet J. 2013;61:1-10.

11. Oates SC, Miller MA, Hardin D, Conrad PA, Melli A, Jessup DA, et al. Prevalence, environmental loading, and molecular characterization of Cryptosporidium and Giardia isolates from domestic and wild animals along the Central California Coast. Appl Environ Microbiol. 2012;78:8762-72.

12. Silverlås C, Bosaeus-Reineck H, Näslund K, Björkman C. Is there a need for improved Cryptosporidium diagnostics in Swedish calves? Int J Parasitol. 2013:43:155-61.

13. Karanis P, Plutzer J, Halim NA, Igori K, Nagasawa H, Ongerth J, et al. Molecular characterization of Cryptosporidium from animal sources in Qinghai province of China. Parasitol Res. 2007;101:1575-80.

14. Efstratiou A, Ongerth JE, Karanis P. Waterborne transmission of protozoan parasites: review of worldwide outbreaks - an update 2011-2016. Water Res. 2017;114:14-22.

15. Hatam-Nahavandi K, Mohebali M, Mahvi AH, Keshavarz H, Najafian HR, Mirjalali H, et al. Microscopic and molecular detection of Cryptosporidium andersoni and Cryptosporidium xiaoi in wastewater samples of Tehran Province, Iran. Iran J Parasitol. 2016;11:499-506.

16. Budu-Amoako E, Greenwood SJ, Dixon BR, Barkema HW, McClure J. Foodborne illness associated with Cryptosporidium and Giardia from livestock. J Food Prot. 2011:74:1944-55.

17. Ryan U, Hijjawi N, Xiao L. Foodborne cryptosporidiosis. Int J Parasitol. 2018;48:1-12

18. Vermeulen LC, Benders J, Medema G, Hofstra N. Global Cryptosporidium loads from livestock manure. Environ Sci Technol. 2017;51:8663-71.

19. Razakandrainibe R, Costa D, Le Goff L, Lemeteil D, Ballet JJ, Gargala $\mathrm{G}$, et al. Common occurrence of Cryptosporidium hominis in asymptomatic and symptomatic calves in France. PLoS Negl Trop Dis. 2018;12:e0006355.

20. Roberts CL, Morin C, Addiss DG, Wahlquist SP, Mshar PA, Hadler JL. Factors influencing Cryptosporidium testing in Connecticut. J Clin Microbiol. 1996;34:2292-3.

21. Chappell CL, Okhuysen PC, Sterling CR, DuPont HL. Cryptosporidium parvum: intensity of infection and oocyst excretion patterns in healthy volunteers. J Infect Dis. 1996;173:232-6.

22. Ryan U, Fayer R, Xiao L. Cryptosporidium species in humans and animals: current understanding and research needs. Parasitoloy. 2014:141:1667-85.

23. Thompson R, Ash A. Molecular epidemiology of Giardia and Cryptosporidium infections. Infect Genet Evol. 2016:40:315-23.

24. Nichols GL, Chalmers RM, Hadfield SJ. Molecular epidemiology of human cryptosporidiosis. Cryptosporidium: parasite and disease. Vienna: Springer; 2014. p. 81-147.

25. Xiao L. Molecular epidemiology of cryptosporidiosis: an update. Exp Parasitol. 2010;124:80-9.

26. Gong C, Cao XF, Deng L, Li W, Huang XM, Lan JC, et al. Epidemiology of Cryptosporidium infection in cattle in China: a review. Parasite. 2017;24:1.

27. Xiao L, Feng Y. Zoonotic cryptosporidiosis. FEMS Immunol Med Microbiol. 2008·52·309-23. 
28. Mueller-Doblies D, Giles M, Elwin K, Smith RP, Clifton-Hadley FA, Chalmers RM. Distribution of Cryptosporidium species in sheep in the UK. Vet Parasitol. 2008;154:214-9.

29. Quílez J, Torres E, Chalmers RM, Hadfield SJ, del Cacho E, SánchezAcedo C. Cryptosporidium genotypes and subtypes in lambs and goat kids in Spain. Appl Environ Microbiol. 2008;74:6026-31.

30. Robertson LJ. Giardia and Cryptosporidium infections in sheep and goats: a review of the potential for transmission to humans via environmental contamination. Epidemiol Infect. 2009;137:913-21.

31. Grinberg A, Learmonth J, Kwan E, Pomroy W, Lopez Villalobos N, Gibson I, Widmer G. Genetic diversity and zoonotic potential of Cryptosporidium parvum causing foal diarrhea. J Clin Microbiol. 2008;46:2396-8.

32. Zintl A, Neville D, Maguire D, Fanning S, Mulcahy G, Smith H, et al. Prevalence of Cryptosporidium species in intensively farmed pigs in Ireland. Parasitology. 2007;134:1575-82.

33. Wagnerová P, Sak B, McEvoy J, Rost M, Sherwood D, Holcomb K, et al. Cryptosporidium parvum and Enterocytozoon bieneusi in American mustangs and Chincoteague ponies. Exp Parasitol. 2016;162:24-7.

34. Wells B, Shaw H, Hotchkiss E, Gilray J, Ayton R, Green J, et al. Prevalence, species identification and genotyping Cryptosporidium from livestock and deer in a catchment in the Cairngorms with a history of a contaminated public water supply. Parasit Vectors. 2015;8:66.

35. García-Presedo I, Pedraza-Díaz S, González-Warleta M, Mezo M, Gómez-Bautista M, Ortega-Mora LM, et al. Presence of Cryptosporidium scrofarum, C. suis and C. parvum subtypes IlaA16G2R1 and IlaA13G1R1 in Eurasian wild boars (Sus scrofa). Vet Parasitol. 2013;196:497-502.

36. Moher D, Liberati A, Tetzlaff J, Altman DG. Preferred reporting items for systematic reviews and meta-analyses: the PRISMA statement. PLoS Med. 2009;6:e1000097.

37. Huson DH, Bryant D. Application of phylogenetic networks in evolutionary studies. Mol Biol Evol. 2006;23:254-67.

38. DerSimonian R, Laird N. Meta-analysis in clinical trials. Control Clin Trials. 1986:7:177-88

39. Hribar A. Understanding concentrated animal feeding operations and their impact on communities. 2010. https://www.cdc.gov/nceh/ehs/ docs/understanding_cafos_nalboh.pdf.

40. Statista. Number of pigs worldwide in 2018 , by leading country (in million head). 2019. https://www.statista.com/statistics/263964/numbe r-of-pigs-in-selected-countries/.

41. Zahedi A, Monis P, Aucote S, King B, Paparini A, Jian F, et al. Zoonotic Cryptosporidium species in animals inhabiting Sydney water catchments. PLOS ONE. 2016:11:e0168169.

42. Jacobson C, Al-Habsi K, Ryan U, Williams A, Anderson F, Yang R, et al. Cryptosporidium infection is associated with reduced growth and diarrhoea in goats beyond weaning. Vet Parasitol. 2018;260:30-7.

43. Sweeny JP, Ryan U, Robertson I, Jacobson C. Cryptosporidium and Giardia associated with reduced lamb carcase productivity. Vet Parasitol. 2011;182:127-39.

44. Thomson S, Hamilton CA, Hope JC, Katzer F, Mabbott NA, Morrison LJ, et al. Bovine cryptosporidiosis: impact, host-parasite interaction and control strategies. Vet Res. 2017:48:42.

45. Benschop J, Booker C, Shadbolt T, Weston J. A Retrospective cohort study of an outbreak of cryptosporidiosis among veterinary students. Vet Sci. 2017;4:E29.

46. Giles M, Chalmers R, Pritchard G, Elwin K, Mueller-Doblies D, CliftonHadley F. Cryptosporidium hominis in a goat and a sheep in the UK. Vet Rec. 2009:164:24-5.

47. Chalmers RM, Giles M. Zoonotic cryptosporidiosis in the UK-challenges for control. J Appl Microbiol. 2010;109:1487-97.

48. Connelly L, Craig B, Jones B, Alexander C. Genetic diversity of Cryptosporidium spp. within a remote population of Soay Sheep on St. Kilda Islands, Scotland. Appl Environ Microbiol. 2013;79:2240-6.

49. Green S, Higgins J. Cochrane handbook for systematic reviews of interventions. 2006. https://training.cochrane.org/handbook.

50. Chalmers RM, Katzer F. Looking for Cryptosporidium: the application of advances in detection and diagnosis. Trends Parasitol. 2013:29:237-51.

51. Gomez-Couso H, Ortega-Mora LM, Aguado-Martinez A, Rosadio-Alcantara R, Maturrano-Hernandez L, Luna-Espinoza L, et al. Presence and molecular characterisation of Giardia and Cryptosporidium in alpacas (Vicugna pacos) from Peru. Vet Parasitol. 2012;187:414-20.
52. Twomey DF, Barlow AM, Bell S, Chalmers RM, Elwin K, Giles M, et al. Cryptosporidiosis in two alpaca (Lama pacos) holdings in the SouthWest of England. Vet J. 2008;175:419-22.

53. Wessels J, Wessels M, Featherstone C, Pike R. Cryptosporidiosis in eightmonth-old weaned alpacas. Vet Rec. 2013:173:426-7.

54. Alves M, Xiao L, Lemos V, Zhou L, Cama V, da Cunha MB, et al. Occurrence and molecular characterization of Cryptosporidium spp. in mammals and reptiles at the Lisbon Zoo. Parasitol Res. 2005;97:108-12.

55. Němejc K, Sak B, Květoňová D, Hanzel V, Jenikova M. The first report on Cryptosporidium suis and Cryptosporidium pig genotype II in Eurasian wild boars (Sus scrofa) (Czech Republic). Vet Parasitol. 2012;184:122-5.

56. Amer S, Zidan S, Feng Y, Adamu H, Li N, Xiao L. Identity and public health potential of Cryptosporidium spp. in water buffalo calves in Egypt. Vet Parasitol. 2013;191:123-7.

57. Helmy AY, Krücken J, Nöckler K, Samson-Himmelstjerna G, Zes$\sin \mathrm{KH}$. Molecular epidemiology of Cryptosporidium in livestock animals and humans in the Ismailia province of Egypt. Vet Parasitol. 2013;193:15-24.

58. Mahfouz ME, Mira NN, Amer S. Prevalence and genotyping of Cryptosporidium spp. in farm animals in Egypt. J Vet Med Sci. 2014;76:1569-75

59. Ibrahim MA, Abdel-Ghany AE, Abdel-Latef GK, Abdel-Aziz SA, Aboelhadid SM. Epidemiology and public health significance of Cryptosporidium isolated from cattle, buffaloes, and humans in Egypt. Parasitol Res. 2016;115:2439-48.

60. Abu Samra N, Jori F, Xiao L, Rikhotso O, Thompson PN. Molecular characterization of Cryptosporidium species at the wildlife/livestock interface of the Kruger National Park, South Africa. Comp Immunol Microbiol Infect Dis. 2013;36:295-302.

61. Abeywardena H, Jex AR, von Samson-Himmelstjerna G, Haydon SR, Stevens MA, Gasser RB. First molecular characterisation of Cryptosporidium and Giardia from Bubalus bubalis (water buffalo) in Victoria, Australia. Infect Genet Evol. 2013;20:96-102.

62. Zahedi A, Phasey J, Boland T, Ryan U. First report of Cryptosporidium species in farmed and wild buffalo from the Northern Territory, Australia. Parasitol Res. 2016;115:1349-53.

63. Caccio SM, Rinaldi L, Cringoli G, Condoleo R, Pozio E. Molecular identification of Cryptosporidium parvum and Giardia duodenalis in the Italian water buffalo (Bubalus bubalis). Vet Parasitol. 2007;150:146-9.

64. Aquino MCC, Widemer G, Zucatto AS, Viol MA, Inacio SV, Nakamura AA, et al. First molecular characterization of Cryptosporidium spp. infecting buffalo calves in Brazil. J Eukaryot Microbiol. 2015;62:657-61.

65. Wang R, Zhang L, Ning C, Feng Y, Jian F, Xiao L, Lu B, Ai W, Dong H. Multilocus phylogenetic analysis of Cryptosporidium andersoni (Apicomplexa) isolated from a Bactrian camel (Camelus bactrianus) in China. Parasitol Res. 2008;102:915-20.

66. Liu X, Zhou X, Zhong Zh, Deng J, Chen W, Cao S, et al. Multilocus genotype and subtype analysis of Cryptosporidium andersoni derived from a Bactrian camel (Camelus bactrianus) in China. Parasitol Res. 2014;113:2129-36.

67. Wegayehu T, Karim R, Anberber M, Adamu H, Erko B, Zhang L, Tilahun G. Prevalence and genetic characterization of Cryptosporidium species in dairy calves in Central Ethiopia. PLoS ONE. 2016;11:e0154647.

68. Szonyi B, Kangethe EK, Mbae CK, Kakundi EM, Kamwati SK, Mohammed $\mathrm{HO}$. First report of Cryptosporidium deer-like genotype in Kenyan cattle. Vet Parasitol. 2008;153:172-5.

69. Kang'ethe EK, Mulinge EK, Skilton RA, Njahira M, Monda JG, Nyongesa C, et al. Cryptosporidium species detected in calves and cattle in Dagoretti, Nairobi, Kenya. Trop Anim Health Prod. 2012;44(Suppl. 1):S25-31.

70. Bodager JR, Parsons MB, Wright PC, Rasambainarivo F, Roellig D, Xiao L, et al. Complex epidemiology and zoonotic potential for Cryptosporidium suis in rural Madagascar. Vet Parasitol. 2015;207:140e143.

71. Ayinmode AB, Fagbemi BO, Xiao L. Molecular characterization of Cryptosporidium spp. in native calves in Nigeria. Parasitol Res. 2010;107:1019-21.

72. Maikai BV, Umoh JU, Kwaga JKB, Lawal I, Maikai VA, Camae V, Xiao L. Molecular characterization of Cryptosporidium spp. in native breeds of cattle in Kaduna State, Nigeria. Vet Parasitol. 2011;178:241-5.

73. Abu Samra N, Jori F, Cacciò SM, Frean J, Poonsamy B, Thompson PN. Cryptosporidium genotypes in children and calves living at the wildlife 
or livestock interface of the Kruger National Park, South Africa. Onderstepoort J Vet Res. 2015;83:a1024.

74. Soltane R, Guyot K, Dei-Cas E, Ayadi A. Prevalence of Cryptosporidium spp. (Eucoccidiorida: Cryptosporiidae) in seven species of farm animals in Tunisia. Parasite. 2007;14:335-8.

75. Geurden T, Goma FY, Siwila J, Phiri IGK, Mwanza AM, Gabriel S, et al. Prevalence and genotyping of Cryptosporidium in three cattle husbandry systems in Zambia. Vet Parasitol. 2006;138:217-22.

76. Wang R, Wang H, Sun Y, Zhang L, Jian F, Qi M, Ning C, Xiao L. Characteristics of Cryptosporidium transmission in preweaned dairy cattle in Henan, China. J Clin Microbiol. 2011;49:1077-82.

77. Wang R, Ma G, Zhao J, Lu Q, Wang H, Zhang L, Jian F, Ning C, Xiao L. Cryptosporidium andersoni is the predominant species in post-weaned and adult dairy cattle in China. Parasitol Int. 2011;60:1-4.

78. Huang J, Yue D, Meng Q, Wang R, Zhao J, Li J, et al. Prevalence and molecular characterization of Cryptosporidium spp. and Giardia duodenalis in dairy cattle in Ningxia, northwestern China. BMC Vet Res. 2014;10:292.

79. Khan SM, Debnath C, Pramanik AK, Xiao L, Nozaki T, Ganguly S. Molecular characterization and assessment of zoonotic transmission of Cryptosporidium from dairy cattle in West Bengal, India. Vet Parasitol. 2010:171:41-7.

80. Meamar AR, Guyot K, Certad G, Dei-Cas E, Mohraz M, Mohebali M, et al. Molecular characterization of Cryptosporidium isolates from humans and animals in Iran. Appl Environ Microbiol. 2007;73:1033-5.

81. Fotouhi Ardakani R, Fasihi Harandi M, Soleiman Banaei S, Kamyabi H, Atapour M, Sharifi I. Epidemiology of Cryptosporidium infection of cattle in Kerman/Iran and molecular genotyping of some isolates. J Kerman Univ Med Sci. 2008:15:313-20

82. Pirestani M, Sadraei J, Dalimi A, Zawar M, Vaeznia H. Molecular characterization of Cryptosporidium isolates from human and bovine using 185 rRNA gene in Shahriar county of Tehran, Iran. Parasitol Res. 2008;103:447-67.

83. Tanriverdi S, Markovics A, Arslan MO, Itik A, Shkap V, Widmer G. Emergence of distinct genotypes of Cryptosporidium parvum in structured host populations. Appl Environ Microbiol. 2006;72:2507-13.

84. Karanis P, Eiji T, Palomino L, Boonrod K, Plutzer J, Ongerth J, Igarashi I. First description of Cryptosporidium bovis in Japan and diagnosis and genotyping of Cryptosporidium spp. in diarrheic pre-weaned calves in Hokkaido. Vet Parasitol. 2010;169:387-90.

85. Halim NA, Plutzer J, Bakheit MA, Karanis P. First report of Cryptosporidium deer-like genotype in Malaysian cattle. Vet Parasitol. 2008:152:325-9.

86. Waldron LS, Dimeski B, Beggs PJ, Ferrari BC, Power ML. Molecular epidemiology, spatiotemporal analysis, and ecology of sporadic human cryptosporidiosis in Australia. App Environ Microbiol. 2011;77:7757-65.

87. Nolan MJ, Jex AR, Mansell PD, Browning GF, Gasser RB. Genetic characterization of Cryptosporidium parvum from calves by mutation scanning and targeted sequencing-zoonotic implications. Electrophoresis. 2009;30:2640-7.

88. Ferguson C. Quantifying Infectious Pathogen Sources in WA Drinking Water Catchments. Report by ASL Water services group. 2010.

89. Ng J, Yang R, McCarthy S, Gordon C, Hijjawi N, Ryan U. Molecular characterization of Cryptosporidium and Giardia in pre-weaned calves in Western Australia and New South Wales. Vet Parasitol. 2011;176:145-50.

90. McCarthy S, Ng J, Gordon C, Miller R, Wyber A, Ryan UM. Prevalence of Cryptosporidium and Giardia species in animals in irrigation catchments in the southwest of Australia. Exp Parasitol. 2008;1 18:596-9.

91. O'Brien E, McInnes L, Ryan U. Cryptosporidium GP60 genotypes from humans and domesticated animals in Australia, North America and Europe. Exp Parasitol. 2008;118:118-21.

92. Ralston B, Thompson RC, Pethick D, McAllister TA, Olson ME. Cryptosporidium andersoni in Western Australian feedlot cattle. Aust Vet J. 2010;88:458-60

93. Learmonth JJ, Ionas G, Pita AB, Cowie RS. Identification and genetic characterisation of Giardia and Cryptosporidium strains in humans and dairy cattle in the Waikato Region of New Zealand. Water Sci Technol. 2003:47:21-6

94. Grinberg A, Lopez-Villalobos N, Pomroy W, Widmer G, Smith H, Tait A. Host-shaped segregation of the Cryptosporidium parvum multilocus genotype repertoire. Epidemiol Infect. 2008;136:273-8.
95. Al-Mawly JA, Grinberg A, Velathanthiri N, French N. Cross-sectional study of prevalence, genetic diversity and zoonotic potential of Cryptosporidium parvum cycling in New Zealand dairy farms. Parasit Vectors. 2015;8:240

96. Geurden T, Berkvens D, Martens C, Casaert S, Vercruysse J, Claerebout E. Molecular epidemiology with subtype analysis of Cryptosporidium in calves in Belgium. Parasitology. 2007;134:1981-7.

97. Kvac M, Kouba M, Vitovec J. Age-related and housing-dependence of Cryptosporidium infection of calves from dairy and beef herds in South Bohemia. Czech Republic. Vet Parasitol. 2006;137:202-9.

98. Kvac M, Hromadova N, Kvetooova D, Rost M, Sak B. Molecular characterization of Cryptosporidium spp. in pre-weaned dairy calves in the Czech Republic: absence of $C$. ryanae and management-associated distribution of C. andersoni, C. bovis and C. parvum subtypes. Vet Parasitol. 2011;177:378-82.

99. Ondrackova Z, Kvac M, Sak B, Kvetonova D, Rost M. Prevalence and molecular characterization of Cryptosporidium spp. in dairy cattle in South Bohemia, the Czech Republic. Vet Parasitol. 2009;165:141-4.

100. Langkjaer RB, Vigre H, Enemark HL, Maddox-Hyttel C. Molecular and phylogenetic characterization of Cryptosporidium and Giardia from pigs and cattle in Denmark. Parasitology. 2007;134:339-50.

101. Enemark HL, Ahrens P, Lowery C, Thamsborg SM, Enemark JMD, Bille-Hansen V, Lind P. Cryptosporidium andersoni from a Danish cattle herd: identification and preliminary characterization. Vet Parasitol. 2002;107:37-49.

102. Follet J, Guyot K, Leruste H, Follet-Dumoulin A, Hammouma-Ghelboun O, Certad G, Dei-Cas E, Halama P. Cryptosporidium infection in a veal calf cohort in France: molecular characterization of species in a longitudinal study. Vet Res. 2011;42:116.

103. Plutzer J, Karanis P. Genotype and subtype analyses of Cryptosporidium isolates from cattle in Hungary. Vet Parasitol. 2007:146:357-62.

104. Thompson HP, Dooley JS, Kenny J, McCoy M, Lowery CJ, Moore JE. Genotypes and subtypes of Cryptosporidium spp. in neonatal calves in Northern Ireland. Parasitol Res. 2007;100:619-24.

105. Duranti A, Caccio SM, Pozio E, Di Egidio A, De Curtis M, Battisti A, Scaramozzino P. Risk factors associated with Cryptosporidium parvum infection in cattle. Zoonoses Public Health. 2009;56:176-82.

106. Rzeżutka A, Kaupke A. Occurrence and molecular identification of Cryptosporidium species isolated from cattle in Poland. Vet Parasitol. 2013;196:301-6.

107. Mendonca C, Almeida A, Castro A, Delgado ML, Soares S, Correia da Costa JM, Canada N. Molecular characterization of Cryptosporidium and Giardia isolates from cattle from Portugal. Vet Parasitol. 2007;147:47-50.

108. Imre K, Lobo ML, Matos O, Popescu C, Genchi C, Dărăbus G. Molecular characterization of Cryptosporidium isolates from pre-weaned calves in Romania: is there an actual risk of zoonotic infections? Vet Parasitol. 2011;181:321-4.

109. Smith HV, Nichols RA, Mallon M, Macleod A, Tait A, Reilly WJ, et al. Natural Cryptosporidium hominis infections in Scottish cattle. Vet Rec. 2005;156:710-1.

110. Misic Z, Abe N. Subtype analysis of Cryptosporidium parvum isolates from calves on farms around Belgrade, Serbia and Montenegro, using the $60 \mathrm{kDa}$ glycoprotein gene sequences. Parasitology. 2007:134:351-8.

111. Quilez J, Torres E, Chalmers RM, Robinson G, Del Cacho E, SanchezAcedo C. Cryptosporidium species and subtype analysis from dairy calves in Spain. Parasitology. 2008;135:1613-20.

112. Cardona GA, de Lucio A, Bailo B, Cano L, de Fuentes I, Carmena D. Unexpected finding of feline-specific Giardia duodenalis assemblage $F$ and Cryptosporidium felis in asymptomatic adult cattle in Northern Spain. Vet Parasitol. 2015:30:258-63.

113. Silverlas C, Blanco-Penedo I. Cryptosporidium spp. in calves and cows from organic and conventional dairy herds. Epidemiol Infect. 2013;141:529-39.

114. Silverlas C, Näslund K, Björkman C, Mattson JG. Molecular characterisation of Cryptosporidium isolates from Swedish dairy cattle in relation to age, diarrhoea and region. Vet Parasitol. 2010;169:289-95.

115. Silverlås C, de Verdier K, Emanuelson U, Mattsson JG, Björkman C. Cryptosporidium infection in herds with and without calf diarrhoeal problems. Parasitol Res. 2010;107:1435-44. 
116. Bjorkman C, Lindstrom L, Oweston C, Ahola H, Troel K, Axen C. Cryptosporidium infections in suckler herd beef calves. Parasitology. 2015;142:1108-14.

117. Uhde FL, Kaufmann T, Sager H, Albini S, Zanoni R, Schelling E, Meylan M. Prevalence of four enteropathogens in the faeces of young diarrhoeic dairy calves in Switzerland. Vet Rec. 2008;163:362-6.

118. Brook EJ, Hart CA, French NP, Christley RM. Molecular epidemiology of Cryptosporidium subtypes in cattle in England. Vet J. 2009;179:378-82.

119. Featherstone CA, Giles M, Marshall JA, Mawhinney IC, Holliman A, Pritchard GC. Cryptosporidium species in calves submitted for postmortem examination in England and Wales. Vet Rec. 2010;167:979-80

120. Moriarty EM, McEvoy JM, Lowery CJ, Thompson HP, Finn M, Sheridan JJ, et al. Prevalence and characterisation of Cryptosporidium species in cattle faeces and on beef carcases at slaughter. Vet Rec. 2005;156:165-8.

121. Smith RP, Chalmers RM, Mueller-Doblies D, Clifton-Hadley FA, Elwin K, Watkins J, Paiba GA, Hadfield SJ, Giles M. Investigation of farms linked to human patients with cryptosporidiosis in England and Wales. Prev Vet Med. 2010;94:9-17.

122. Coklin T, Farber J, Parrington L, Dixon B. Prevalence and molecular characterization of Giardia duodenalis and Cryptosporidium spp. in dairy cattle in Ontario, Canada. Vet Parasitol. 2007;150:297-305.

123. Coklin T, Uehlinger FD, Farber JM, Barkema HW, O'Handley RM, Dixon B. Prevalence and molecular characterization of Cryptosporidium spp. in dairy calves in 11 farms in Prince Edward Island, Canada. Vet Parasitol. 2009;160:323-6.

124. Budu-Amoako E, Greenwood SJ, Dixon BR, Barkema HW, McClure JT. Giardia and Cryptosporidium on dairy farms and the role these farms may play in contaminating water sources in Prince Edward Island, Canada. J Vet Intern Med. 2012;26:668-73.

125. Budu-Amoako E, Greenwood SJ, Dixon BR, Barkema HW, McClure JT. Occurrence of Cryptosporidium and Giardia on beef farms and water sources within the vicinity of the farms on Prince Edward Island Canada. Vet Parasitol. 2012;184:1-9.

126. Santín M, Trout JM, Xiao L, Zhou L, Greiner E, Fayer R. Prevalence and age-related variation of Cryptosporidium species and genotypes in dairy calves. Vet Parasitol. 2004;122:103-17.

127. Fayer R, Santın M, Trout JM, Greiner E. Prevalence of species and genotypes of Cryptosporidium found in 1-2-year-old dairy cattle in the eastern United States. Vet Parasitol. 2006;135:105-12.

128. Fayer R, Santin M, Trout JM. Prevalence of Cryptosporidium species and genotypes in mature dairy cattle on farms in eastern United States compared with younger cattle from the same locations. Vet Parasitol. 2007;145:260-6.

129. Fayer R, Santín M, Dargatz D. Species of Cryptosporidium detected in weaned cattle on cow-calf operations in the United States. Vet Parasitol. 2010:170:187-92.

130. Szonyi B, Bordonaro R, Wade SE, Mohammed HO. Seasonal variation in the prevalence and molecular epidemiology of Cryptosporidium infection in dairy cattle in the New York City Watershed. Parasitol Res. 2010;107:317-25.

131. Meireles MV, Oliveira FP, Teixeira WF, Coelho WM, Mendes LC. Molecular characterization of Cryptosporidium spp. in dairy calves from the state of São Paulo, Brazil. Parasitol Res. 2011;109:949-51.

132. Sevá AP, Funada MR, Souza SO, Nava A, Richtzenhain LJ, Soares RM. Occurrence and molecular characterization of Cryptosporidium spp. isolated from domestic animals in a rural area surrounding Atlantic dry forest fragments in Teodoro Sampaio municipality, State of São Paulo, Brazil. Rev Bras Parasitol Vet. 2010;19:249-53.

133. Silva FM, Lopes RS, Araújo-Junior JP. Identification of Cryptosporidium species and genotypes in dairy cattle in Brazil. Rev Bras Parasitol Vet. 2013;22:22-8

134. Kodádková A, Kváč M, Ditrich O, Sak B, Xiao L. Cryptosporidium muris in a reticulated giraffe (Giraffa camelopardalis reticulata). J Parasitol. 2010;96:211-2.

135. Parsons MB, Travis D, Lonsdorf EV, Lipende I, Roellig DM, Collins A, et al. Epidemiology and molecular characterization of Cryptosporidium spp. in humans, wild primates, and domesticated animals in the Greater Gombe Ecosystem, Tanzania. PLoS Negl Trop Dis. 2015;20:e0003529.

136. Goma FY, Geurden T, Siwila J, Phiri IGK, Gabriel S, Claerebout E, et al. The prevalence and molecular characterisation of Cryptosporidium spp. in small ruminants in Zambia. Small Ruminant Res. 2007:72:77-80.
137. Wang R, Li G, Cui B, Huang J, Cui Z, Zhang S, et al. Prevalence, molecular characterization and zoonotic potential of Cryptosporidium spp. in goats in Henan and Chongqing, China. Exp Parasitol. 2014;142:11-6.

138. Koinari M, Lymbery AJ, Ryan UM. Cryptosporidium species in sheep and goats from Papua New Guinea. Exp Parasitol. 2014;141:134-7.

139. Geurden T, Thomas P, Casaert S, Vercruysse J, Claerebout E. Prevalence and molecular characterisation of Cryptosporidium and Giardia in lambs and goat kids in Belgium. Vet Parasitol. 2008;155:142-5.

140. Rieux A, Paraud C, Pors I, Chartier C. Molecular characterization of Cryptosporidium spp. in pre-weaned kids in a dairy goat farm in western France. Vet Parasitol. 2013;192:268-72.

141. Paraud C, Pors I, Rieux A, Brunet S. High excretion of Cryptosporidium ubiquitum by peri-parturient goats in one flock in western France. Vet Parasitol. 2014;202:301-4

142. Tzanidakis N, Sotiraki S, Claerebout E, Ehsan A, Voutzourakis N, Kostopoulou D, et al. Occurrence and molecular characterization of Giardia duodenalis and Cryptosporidium spp. in sheep and goats reared under dairy husbandry systems in Greece. Parasite. 2014;21:45.

143. Diaz P, Quilez J, Robinson G, Chalmers RM, Diez-Banos P, Morrondo P. Identification of Cryptosporidium xiaoi in diarrhoeic goat kids (Capra hircus) in Spain. Vet Parasitol. 2010;172:132-4.

144. Díaz P, Quílez J, Prieto A, Navarro E, Pérez-Creo A, Fernández G, et al. Cryptosporidium species and subtype analysis in diarrhoeic preweaned lambs and goat kids from north-western Spain. Parasitol Res. 2015;114:4099-105.

145. Laatamna AK, Wagnerová P, Sak B, Květoňová D, Aissi M, Rost M, et al. Equine cryptosporidial infection associated with Cryptosporidium hedgehog genotype in Algeria. Vet Parasitol. 2013;197:350-3.

146. Liu A, Zhang J, Zhao J, Zhao W, Wang R, Zhang L. The first report of Cryptosporidium andersoni in horses with diarrhea and multilocus subtype analysis. Parasit Vectors. 2015;8:483.

147. Galuppi R, Piva S, Castagnetti C, lacono E, Tanel S, Pallaver F, et al. Epidemiological survey on Cryptosporidium in an Equine Perinatology Unit. Vet Parasitol. 2015;210:10-8.

148. Chalmers AM, Thomas AL, Butler BA, Davies Morel MCG. Identification of Cryptosporidium parvum genotype 2 in domestic horses. Vet Rec. 2005;159:49-50.

149. Burton AJ, Nydam DV, Dearen TK, Mitchell K, Bowman DD, Xiao L. The prevalence of Cryptosporidium, and identification of the Cryptosporidium horse genotype in foals in New York State. Vet Parasitol. 2010;174:139-44.

150. Kotková M, Němejc K, Sak B, Hanzal V, Květoňová D, Hlásková L, et al. Cryptosporidium ubiquitum, C. muris and Cryptosporidium deer genotype in wild cervids and caprines in the Czech Republic. Folia Parasitol. 2016;63:003.

151. Morgan UM, Deplazes P, Forbes DA, Spano F, Hertzberg H, Sargent KD, et al. Sequence and PCR-RFLP analysis of the internal transcribed spacers of the rDNA repeat unit in isolates of Cryptosporidium from different hosts. Parasitology. 1999;18:49-58.

152. Johnson J, Buddle R, Reid S, Armson A, Ryan U. Prevalence of Cryptosporidium genotypes in pre and post-weaned pigs in Australia. Exp Parasitol. 2008;119:418-21.

153. Ryan UM, Samarasinghe B, Read C, Buddle JR, Robertson ID, Thompson RCA. Identification of a novel Cryptosporidium genotype in pigs. Appl Environ Microbiol. 2003:69:3970-4.

154. Vitovec J, Hamadejova K, Landova L, Kvac M, Kvetonova D, Sak B. Prevalence and pathogenicity of Cryptosporidium suis in pre- and postweaned pigs. J Vet Med B. 2006;53:239-43.

155. Kváč M, Sak B, Hanzlíková D, Kotilová J, Květoňová D. Molecular characterization of Cryptosporidium isolates from pigs at slaughterhouses in South Bohemia, Czech Republic. Parasitol Res. 2009;104:425-8.

156. Kváč M, Hanzlíková D, Sak B, Květoňová D. Prevalence and age-related infection of Cryptosporidium suis, C. muris and Cryptosporidium pig genotype II in pigs on a farm complex in the Czech Republic. Vet Parasitol. 2009;160:319-22.

157. Němejc K, Sak B, Květoňová D, Kernerová N, Rost M, Cama VA, Kváč M. Occurrence of Cryptosporidium suis and Cryptosporidium scrofarum on commercial swine farms in the Czech Republic and its associations with age and husbandry practices. Parasitol Res. 2013;112:1143-54.

158. Petersen $\mathrm{HH}$, Jianmin W, Katakam KK, Mejer H, Thamsborg SM, Anders Dalsgaard A, et al. Cryptosporidium and Giardia in Danish organic pig 
farms: seasonal and age-related variation in prevalence, infection intensity and species/genotypes. Vet Parasitol. 2015;214:29-39.

159. Featherstone CA, Marshall JA, Giles M, Sayers AR, Pritchard GC. Cryptosporidium species infection in pigs in East Anglia. Vet Rec. 2010;166:51-2.

160. Fiuza VRS, Gallo SSM, Frazao-Teixeira E, Santın M, Fayer R, Oliveira FCR. Cryptosporidium pig genotype II diagnosed in Pigs from the State of Rio De Janeiro. Brazil J Parasitol. 2011;97:146-7.

161. García-Presedo I, Pedraza-Díaz S, González-Warleta M, Mezo M, GómezBautista M, Ortega-Mora LM, et al. The first report of Cryptosporidium bovis, C. ryanae and Giardia duodenalis sub-assemblage A-II in roe deer (Capreolus capreolus) in Spain. Vet Parasitol. 2013;197:658-64.

162. Wang Y, Feng Y, Cui B, Jian F, Ning C, Wang R, Zhang L, Xiao L. Cervine genotype is the major Cryptosporidium genotype in sheep in China. Parasitol Res. 2010;106:341-7.

163. Li P, Cai J, Cai M, Wu W, Li C, Lei M, et al. Distribution of Cryptosporidium species in Tibetan sheep and yaks in Qinghai, China. Vet Parasitol. 2016;215:58-62.

164. Yang R, Jacobson C, Gardner G, Carmichael I, Campbell AJD, Ng-Hublin $J$, et al. Longitudinal prevalence, oocyst shedding and molecular characterisation of Cryptosporidium species in sheep across four states in Australia. Vet Parasitol. 2014;200:50-8.

165. Ryan UM, Bath C, Robertson I, Read C, Elliot A, Mcinnes L, Traub R, Besier B. Sheep may not be an important zoonotic reservoir for Cryptosporidium and Giardia parasites. Appl Environ Microbiol. 2005;71:4992-7.

166. Yang R, Jacobson C, Gordon C, Ryan U. Prevalence and molecular characterisation of Cryptosporidium and Giardia species in pre-weaned sheep in Australia. Vet Parasitol. 2009;161:19-24.

167. Yang R, Gardner GE, Ryan U, Jacobson C. Prevalence and pathogen load of Cryptosporidium and Giardia in sheep faeces collected from saleyards and in abattoir effluent in Western Australia. Small Ruminant Res. 2015;130:216-22.
168. Imre K, Luca C, Costache M, Sala C, Morar A, Morariu S, et al. Zoonotic Cryptosporidium parvum in Romanian newborn lambs (Ovis aries). Vet Parasitol. 2013;191:119-22.

169. Díaz P, Quílez J, Chalmers RM, Panadero R, López C, Sánchez-Acedo C. Genotype and subtype analysis of Cryptosporidium isolates from calves and lambs in Galicia (NW Spain). Parasitology. 2010;137:1187-93.

170. Pritchard GC, Marshall JA, Giles M, Muller-Doblies D, Sayers AR, Marshall RN, et al. Cryptosporidium species in lambs submitted for diagnostic postmortem examination in England and Wales. Vet Rec 2008;163:688-9.

171. Fiuza VR, Cosendey Rl, Frazão-Teixeira E, Santín M, Fayer R, Oliveira FC. Molecular characterization of Cryptosporidium in Brazilian sheep. Vet Parasitol. 2011;175:360-2.

172. Paz e Silva FM, Lopes RS, Saraiva Bresciani KD, Talamini Amarante AF, Araujo JP Jr. High occurrence of Cryptosporidium ubiquitum and Giardia duodenalis genotype E in sheep from Brazil. Acta Parasitol. 2014:59:193-6.

173. Zucatto AS, Aquino MCC, Inácio SV, Fiqueiredo RN, Pierucci JC, Perri $\mathrm{SHV}$, et al. Molecular characterisation of Cryptosporidium spp. in lambs in the South-Central region of the State of São Paulo. Arq Bras Med Vet Zootec. 2015;67:441-6.

\section{Publisher's Note}

Springer Nature remains neutral with regard to jurisdictional claims in published maps and institutional affiliations.
Ready to submit your research? Choose BMC and benefit from:

- fast, convenient online submission

- thorough peer review by experienced researchers in your field

- rapid publication on acceptance

- support for research data, including large and complex data types

- gold Open Access which fosters wider collaboration and increased citations

- maximum visibility for your research: over 100M website views per year

At BMC, research is always in progress.

Learn more biomedcentral.com/submissions 